\title{
The Memory Wars: Debates on the Holocaust and the Legacy of anti-Semitism in Poland
}

Jonathan Andrew Bergquist

Follow this and additional works at: https://researchrepository.wvu.edu/etd

\section{Recommended Citation}

Bergquist, Jonathan Andrew, "The Memory Wars: Debates on the Holocaust and the Legacy of antiSemitism in Poland" (2015). Graduate Theses, Dissertations, and Problem Reports. 5188.

https://researchrepository.wvu.edu/etd/5188

This Thesis is protected by copyright and/or related rights. It has been brought to you by the The Research Repository @ WVU with permission from the rights-holder(s). You are free to use this Thesis in any way that is permitted by the copyright and related rights legislation that applies to your use. For other uses you must obtain permission from the rights-holder(s) directly, unless additional rights are indicated by a Creative Commons license in the record and/ or on the work itself. This Thesis has been accepted for inclusion in WVU Graduate Theses, Dissertations, and Problem Reports collection by an authorized administrator of The Research Repository @ WVU. For more information, please contact researchrepository@mail.wvu.edu. 
The Memory Wars: Debates on the Holocaust and the Legacy of anti-Semitism in Poland

Jonathan Andrew Bergquist

\author{
Thesis submitted to the \\ College of Arts and Sciences \\ at West Virginia University \\ in partial fulfillment of the requirements \\ for the degree of
}

Master of Arts

in

History
Robert Blobaum, Ph.D., Chair
Joshua Arthurs, Ph.D.
Joseph Hodge, Ph.D.
Department of History

Morgantown, West Virginia

2015

Keywords: Polish-Jewish Relations; the Holocaust; Collective Memory; anti-Semitism Copyright 2015 Jonathan Andrew Bergquist 


\begin{abstract}
The Memory Wars: Debates on the Holocaust and the Legacy of anti-Semitism in Poland
\end{abstract}

\author{
Jonathan Andrew Bergquist
}

The process of Vergangenheitsbewältigung, or mastering the past, is often slow and painful. All too often nations have a tendency to celebrate their past triumphs while forgetting or marginalizing the most traumatic episodes of their histories. The case of Poland is particularly interesting - especially in connection to the disappearance of the country's minority Jewish heritage. Poland, of course, was the primary site of the Holocaust, and the nearly complete destruction of the country's once vast Jewish population, which had been the largest in the world, has left a troublesome legacy behind. How had such horrific crimes taken place on Polish soil? What role had Poles played in the Nazi slaughter of Jews? Had Poles been complicit in this atrocity? Or — even worse-were there cases in which Poles had actually participated in the barbaric, genocidal violence against Jews? During the communist era, most Poles did not seriously wrestle with the moral problems that arose from the virtual disappearance of Polish Jewry; by contrast, the last few decades have seen a dramatic change as Poland has transitioned from a communist to a post-communist society. Indeed, since the 1980s Poland has embarked upon a process of major soul-searching, and a series of vexing and polemical debates have captured the spotlight in Poland in recent years. This thesis seeks to analyze these debates and to assess how the Polish memory of the Holocaust has evolved during this time. Finally, this thesis attempts to understand the current status of Polish-Jewish relations, especially in relation to the controversies over the Polish-Jewish past. 


\section{Acknowledgements}

Completing any scholarly project of magnitude requires considerable assistance along the way, and I owe many debts to those who have aided me while I worked on this thesis. First and foremost, I would like to thank my advisor at WVU, Dr. Robert Blobaum, as well as my advisor at Collegium Civitas, Dr. Dariusz Stola. Both Dr. Blobaum and Dr. Stola displayed a sincere willingness to help me develop my ideas, and both offered constant encouragement and invaluable feedback at various stages of my research. Additionally, I would like to thank Dr. Joshua Arthurs, who provided important advice when this project first began to take form and who later served on my committee. Finally, I would like to thank Lucas Pennock, a fellow graduate student at WVU, who read and critiqued an early draft of this thesis.

In addition to the aforementioned individuals who helped develop and clarify the direction of my research, I am grateful for WVU's Atlantis Program, which is run by Dr. Blobaum, and the generous scholarship provided through the Fund for the Improvement of Education (FIPSE), which made it possible to live and study for a semester in both Estonia and Poland. Had it not been for my experiences abroad, particularly in Warsaw, this project would have been inconceivable. To all the others who supported my while I worked on this thesis, particularly close friends and family, I would also like to express my deepest gratitude. 


\section{TABLE OF CONTENTS}

Chapter One: Contextualizing the Memory Wars .1

I. Introduction......................................................

II. Research Motivation and Methodology...............................6

Chapter Two: Early Challenges to Polish Memory ….............................10

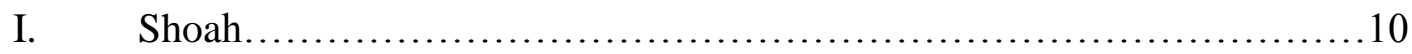

II. The Poor Poles Look at the Ghetto...................................13

III. Remembering Auschwitz..........................................17

Chapter Three: The Neighbors Controversy ....................................27

I. Debate among Scholars and in the Polish Press.............................29

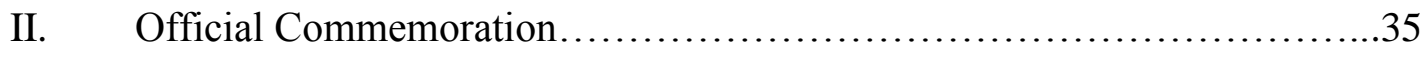

III. Artistic Commemoration.............................................41

Chapter Four: Other Works by Gross .........................................

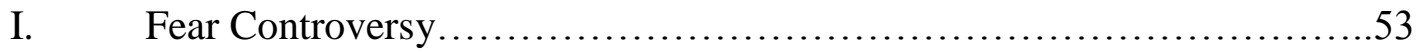

II. Golden Harvest Controversy.........................................58

Chapter Five: Current Status of Polish-Jewish Relations...........................64

I. POLIN Museum of the History of Polish Jews...........................65

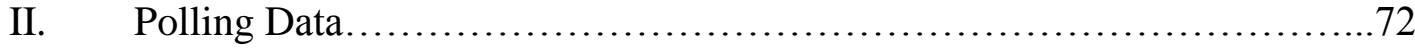

Chapter Six: Moral Responsibility and Polish-Jewish Reconciliation..................80

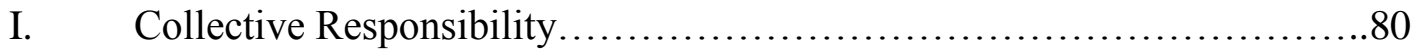

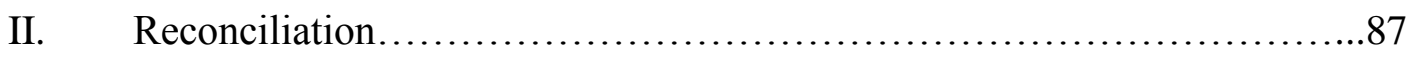

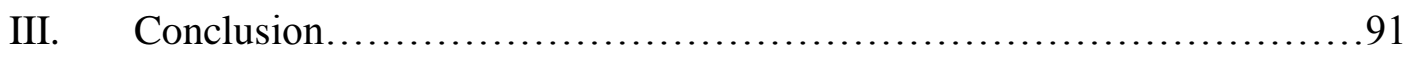

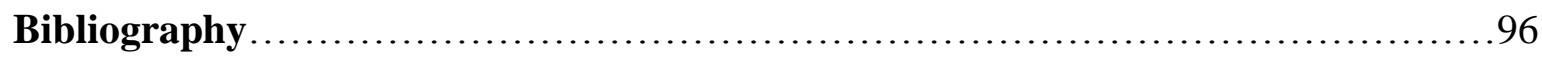

I. Primary Sources..................................................... 96

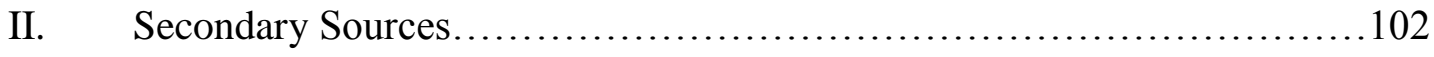




\section{Chapter One: Contextualizing the Memory Wars}

\section{Introduction}

On Tłomackie Street in Warsaw, the capital of Poland, there once stood a Great Synagogue that was known throughout the world for its size, beauty and grandeur. At the time of its construction in 1878, it was the largest synagogue in the world and a powerful symbol of the richness of Jewish life in Poland. But now, where the Great Synagogue once stood, the Btękitny Wieżowiec, or Blue Skyscraper, now stands - a testament to capitalism and the country's march toward progress and economic prosperity. Like so many Jewish cultural monuments, Warsaw's most impressive synagogue did not survive the devastation of the Second World War. All around Poland the modern world collides with history. Even Warsaw itself, a city that was razed to the ground by Hitler's forces, seems forever caught between two worlds, perpetually stuck in the struggle between remembering and forgetting. But the horrors of the Holocaust would make it far more difficult to speak of the memory of Polish Jews; moreover, the absence of Jewish life has left a void in Poland, a vast chasm of collective amnesia for what was once Europe's largest and most vibrant community of Jews. But what would come to fill this void in the aftermath of the war? And what would happen when this missing history — and the memory of the millions of Jews systematically murdered during WWII-resurfaced?

The history of the Holocaust, of course, is no ordinary history. Indeed, the Holocaust represents by far the darkest event in twentieth-century European history. In what was supposed to be the age of modernity, an era of inexorable progress on all fronts, a collapse into such total genocidal barbarism seemed absurd and impossible. ${ }^{1}$ How could post-Enlightenment Europe

\footnotetext{
${ }^{1}$ It has also been argued, however, that modernity itself was a necessary precursor to the Holocaust; for this perspective, see Zygmunt Bauman, Modernity and the Holocaust (Ithaca: Cornell University Press, 1989).
} 
have been the site of such egregious death and despair? In the immediate aftermath of the war, culpability for all of the unfathomable carnage seemed obvious to many. Total blame in Europe was placed on Nazi Germany and its racist, fascistic ideology. In this way fascism—and especially Nazism - became synonymous with evil. Indeed, according to this interpretation, despite their sincere resistance, the various nations under German occupation were powerless as Hitler massacred the Jews of Europe. This myth, which found the Nazis alone guilty for all the war's mass murder and genocide, could not survive the scrutiny of rigorous historical scholarship. ${ }^{2}$ The harsh reality turned out to be that throughout much of occupied Europe there was widespread collaboration and complicity with the Nazi regime, a fact now well documented by historians.

All across Europe historians have now subverted collective memory by challenging celebratory, nationalistic narratives that sought to obscure the historical record. In the case of France, for example, the extent and enthusiasm of Vichy collaboration has now been extensively studied by scholars. ${ }^{3}$ In Germany, too, scholars have played an indispensable role in the struggle against historical obfuscation. Whereas many Germans sought to portray the Wehrmacht as an institution essentially innocent of the evils of the Nazi regime, this myth has now been essentially devastated by contemporary scholarship. ${ }^{4}$ Of course, many German historians have also fiercely resisted the scholarship that they perceived as condemning their nation. It should come as no surprise that Germany was home to the Historikerstreit, or historians' quarrel, in

\footnotetext{
${ }^{2}$ For a brief description how this myth was cultivated, see Tony Judt, "The Past is Another Country," Daedalus 121, no. 4 (Fall 1992).

${ }^{3}$ See, for example, Robert Paxton, Vichy France: Old Guard and New Order, 1940-1944 (New York: Alfred A Knopf, 1972); also see Michael R. Marrus and Robert Paxton, Vichy France and the Jews (New York: Basic Books, 1981).

${ }^{4}$ This is well documented, for instance, in Omer Bartov, Hitler's Army: Soldiers, Nazis, and War in the Third Reich (Oxford University Press, 1992); furthermore, see Waitman Wade Beorn, Marching into Darkness: The Wehrmacht and the Holocaust in Belarus (Cambridge: Harvard University Press, 2014).
} 
which historians dueled over the uniqueness of the Holocaust and the inevitability of Nazism. A similar debate spawned by Daniel Goldhagen's Hitler's Willing Executioners, ${ }^{5}$ which argued that a unique bloodthirsty "eliminationist" anti-Semitism was so deeply rooted in German history and society that it affected how virtually all Germans viewed Jews during the Second World War. Especially in the countries that were under Nazi occupation, it is important to note that none of these challenges to post-war collective memory should be conceived as relativizing the crimes of Hitler's regime. Nor do they absolve the Third Reich of any crime - whether individual or collective — committed during Hitler's reign. Still, these claims of collaboration (and sometimes worse) were deeply troubling. The moral legacy of much of Europe was at stake.

In contrast to Western Europe, and in part due to the dictatorial communist regimes that suppressed memory, Eastern Europeans lagged behind when it came to confronting their respective histories. ${ }^{6}$ But the floodgates of history have been blasted open in recent years and suppressed memory has returned with a vengeance throughout Central and Eastern Europe. ${ }^{7}$ The case of Poland, of course, is no exception. Quite the opposite in fact: post-communist Poland has emerged as the region's leader in terms of wrestling with the politics of memory and history. Much of this struggle is concerned with coming to terms with the country's communist past. Other mnemonic struggles have concerned Polish-German or Polish-Ukrainian relations. Perhaps most importantly, however, in recent years Poland has embarked upon a process of reassessing the Holocaust and the Polish-Jewish past much more broadly. The ensuing debates

\footnotetext{
${ }^{5}$ Daniel Goldhagen, Hitler's Willing Executioners: Ordinary Germans and the Holocaust (New York: Alfred A. Knopf); Goldhagen's understanding of German anti-Semitism has been criticized-justifiably—by many historians. For a good discussion of some of the problems inherent in Goldhagen's book, see Christopher Browning, review of Hitler's Willing Executioners, History and Memory 8, no.1 (Spring-Summer 1996): 88-108.

${ }^{6}$ Judt, 109.

${ }^{7}$ For a fascinating collection of essays on the struggle over memory of the Holocaust that covers the entire region, see John-Paul Himka and Joanna Beata Michlic, ed., Bringing the Dark Past to Light: The Reception of the Holocaust in Postcommunist Europe (Lincoln: University of Nebraska Press, 2013).
} 
and discussions - which I designate the Memory Wars - have generated enormous controversy and confusion throughout the country.

Before diving into the Memory Wars, however, it is necessary to provide some historical context. The roughly 1000 year history of Polish Jews - much like the history of Poland more generally ${ }^{8}$ - is quite complex. Jewish migration to Poland, particularly beginning in the fourteenth century, occurred for several reasons: first, it was partially caused by religious persecution in the West - especially in the Germanic states; and secondly, it was partially caused by Polish monarchs who offered greater tolerance and better economic prospects than Western leaders in order to increase the populations of their own lands and enhance their revenue through taxation. ${ }^{9}$ Prior to the modern era, Polish-Jewish relations were rarely characterized by violence; in fact, it has been poignantly noted that the relationship between Poles and Jews could perhaps best be described as "mutual good natured contempt."10 At some point, however, this good natured contempt evolved into something far more sinister. Exactly how and when this happened, it is fair to say, is a question that is open to interpretation. Theodore R. Weeks, for example, provides one very plausible explanation. Weeks maintains that the birth of nationalism in Poland, which occurred in a unique situation compared to the rest of Central and Eastern Europe, was crucial. Unlike in these other countries, Poland had developed a thriving high culture and had attained political independence only to be subjugated by the end of the eighteenth century. Partially as a result of the perceived existential threat posed by the Russian

\footnotetext{
${ }^{8}$ For an in depth examination of Polish history, see Norman Davies, God's Playground: A History of Poland, Volume I and II (New York: Columbia University Press, 2005).

${ }^{9}$ Robert Blobaum, introduction to Antisemitism and its Opponents in Modern Poland, ed. Robert Blobaum (Ithaca: Cornell University Press, 2005), 2.

${ }^{10}$ Ibid.
} 
Empire ${ }^{11}$ which was where most Poles lived in the late nineteenth and early twentieth centuries, the lack of Jewish assimilation with mainstream Polish culture was perceived in an especially negative light. Moreover, anti-Semitic attitudes imported from the West, coupled with Catholic influence, also played a contributing factor. ${ }^{12}$ When the Polish state reemerged during the interwar period, it was clear that attitudes toward Jews had deteriorated drastically. Following a surge of ethno-nationalism, there was a wave of anti-Semitic violence in Poland. This was often followed by a celebration of the perpetrators of such acts as national heroes and a shifting of blame for such violence onto Jews. ${ }^{13}$ This anti-Semitic violence would continue to escalate until climaxing during and after the Second World War. More specific details about the exact nature of crimes committed will be dealt with in subsequent chapters.

More needs to be said about what the Memory Wars actually are and how they came to be. It is worth pointing out that the reassessment of the Polish-Jewish past emerged at a particular historical moment and that this was no coincidence. During the communist era, Poles and Jews were portrayed in solidarity with one another and any discussion of anti-Semitic violence by Poles — if it was publicly mentioned at all—was always marginalized. ${ }^{14}$ When Karol Józef Wojtyła, who would come to be known as John Paul II, was elected Pope in 1978, it inspired the Polish nation like no other event in decades and helped to lay the foundations for the mass opposition of the Solidarność, or Solidarity, movement of the 1980s. Eventually, this non-

${ }^{11}$ The anxiety over the existential threat described by Weeks would eventually erupt into revolution and major social upheaval; see, for example, Robert Blobaum, Rewolucja: Russian Poland, 1904-1907 (Ithaca: Cornell University Press, 1995), which describes the underlying social tensions that contributed to the political turmoil.

${ }^{12}$ Theodore R. Weeks, “Assimilation, Nationalism, Modernization," in Antisemitism and its Opponents in Modern Poland, 20-38.

${ }^{13}$ Joanna Beata Michlic, Poland's Threatening Other: The Image of the Jew from 1880 to the Present (Lincoln: University of Nebraska Press, 2006), 109.

${ }^{14}$ Joanna Beata Michlic, Coming to Terms with the "dark past": The Polish Debate about the Jedwabne Massacre (Hebrew University of Jerusalem, 2002), 3. 
violent revolutionary movement would lead to the Round Table talks of 1989 and the collapse of the communist government. With the new political climate made possible by Solidarność, Poles began to slowly reexamine their recent history, including the Polish-Jewish past. ${ }^{15}$ Then, in the 1990s, Poland embarked upon a major period of transition, undergoing shock therapy based economic reforms and rapid democratization. In 1991, Poland was a founding member of the Visegrad Group, which would pave the way for later NATO and EU accession. In short, this was a transformational time in Polish history. It was a period marked by vast challenges to authority and conventional wisdom, major social upheaval and a fundamental reorientation of Polish politics. It is unsurprising, therefore, that challenges to Polish collective memory would begin to emerge during this tumultuous period of unrest and rapid social change.

\section{Research Motivation and Methodology}

This thesis will investigate the role the Memory Wars have played in framing — or perhaps more accurately reframing-Polish understanding of Polish-Jewish relations. Furthermore, it will analyze the diverse responses of Poles to the new interpretations of the Second World War and the Holocaust that have appeared since the end of communist rule in Poland. This discussion will be broad. It will be informed by the reactions of Polish scholars, artists and filmmakers, government officials and numerous journalists. Other problems or questions will be addressed along the way. What role, for example, have these debates played in shaping or altering the representation of Jews in Poland? How have Poles dealt with—or, when relevant, failed to deal with - the demons of their past? The vast debates over Polish-Jewish

\footnotetext{
${ }^{15} \mathrm{Ibid}, 4-5$.
} 
relations at the heart of the Memory Wars will be used as a conceptual tool to explore these larger issues.

This project will ideally result in at least three important outcomes. First and foremost, it will show that historians have not merely retreated to their ivory towers, engaged in abstruse debates far removed from anything of any relevance or concern to the general public. On the contrary, many of the issues historians grapple with often have massive implications for collective memory and real world social problems. Secondly, this project will attempt to show that dealing with the hard problems of the past is no meaningless intellectual exercise. Confronting a troubled history can instead have profound social implications, which alter the way nations envision their past and their future. Thirdly, to the extent that Poland has been successful in wrestling with its past, this project can help shed light on why that might be and how other European nations, which maybe have not been as successful as Poland in this regard, can learn from its example.

Ultimately, it will be argued that the Memory Wars are part of a broad trend underway in Polish society that that is tied to Poland's democratization. The main goal is not to demonstrate a strong causal link between the Memory Wars and a profound change in Polish attitudes. In fact, no such profound change has occurred, and the most recent controversies over the PolishJewish past demonstrate that the Memory Wars are as hotly contested as ever. It will be asserted, however, that the reassessment of the Polish-Jewish past — exemplified in the works of various scholars, journalists and other figures — represents the most serious and provocative challenge to Poland's national memory in the country's history. Indeed, as a result of numerous attempts over the last several decades to undermine the nationalistic narratives that emerged in the aftermath of the Second World War, Poland is now dealing with its own version of 
Vergangenheitsbewältigung, or mastering the past, a notion of crucial importance in the German historiography of the Holocaust. Poland's Vergangenheitsbewältigung has not been an easy journey; indeed, it has been a constant back-and-forth struggle, and there are still disturbing right-wing and ultra-nationalistic tendencies that emerge whenever the Polish-Jewish past enters into public discourse. The process of coming to terms with the past in Poland, it must furthermore be pointed out, cannot be reduced to a single debate or incident; instead, Poland's Vergangenheitsbewältigung must be understood as part of a broad, cumulative process that began to pick up steam in the 1980 s and is still very much ongoing. This process accelerated in the early 2000s when, for the first time, significant numbers of Poles began to recognize the importance of accepting responsibility for their history. While the empirical evidence on the current status of anti-Semitism in contemporary Poland remains unclear, although anti-Semitism undoubtedly is still pervasive throughout Poland, it will nevertheless be argued that Poland's willingness to confront the demons of history is a crucial step toward atonement and reconciliation.

This project is conceived as an intended contribution to the field of memory studies, an interdisciplinary field which has helped to transform the humanities and the social sciences over the last several decades. Because this project focuses on how Poles conceive of their history, the distinction between primary and secondary sources is necessarily blurred and arguably breaks down entirely. Texts which might ordinarily be conceived as secondary sources are sometimes reformulated as primary sources and as expressions of Polish memory. This project also draws heavily on films, newspapers and official political statements. In recent years a huge body of literature debating the Polish-Jewish past has appeared in both Polish and, to a lesser extent, English. Much of the recent historiography on the Polish-Jewish past can be construed in one of 
two ways: first, there is a large body of literature which attacks (or defends) the aforementioned nationalistic narratives of WWII; and secondly, there is a much smaller body of literature which discusses Polish memory more generally. This thesis, ultimately, contributes to both of these literatures. First and foremost, this thesis is the most up-to-date presentation of Polish-Jewish relations and it analyzes, contextualizes and brings together these various mnemonic controversies in ways unlike any other academic source. Secondly, this project attempts to incorporate polling data into the discussion, which helps make its analysis a little less elite driven than what has prevailed in most of the existing literature. Thirdly, much of what has been written utilizes concepts like "collective responsibility" and "reconciliation" in a vague and often unsophisticated way. This project thus seeks to bring some much needed analytical clarity toward these sorts of issues, the amorphous nature of which undoubtedly has been one of the key impediments to making progress in these debates. 


\section{Chapter Two: Early Challenges to Polish Memory}

\section{Shoah}

The Polish response to Claude Lanzmann's 1985 film Shoah represents one of the earliest manifestations of the Memory Wars. Indeed, the French filmmaker's nearly ten hour documentary provoked tremendous anger in Poland due to its perceived emphasis on the complicity of Poles in the Nazi extermination of Jews and a lack of emphasis on issues like Polish suffering and heroism during the war. As a result of these alleged shortcomings, Jerzy Turowicz, a leading Polish journalist at the time, described Lanzmann's groundbreaking film as "biased" and "anti-Polish."16 Outside of Poland, however, Shoah was generally met with high praise. In the United States, for example, Pulitzer Prize-winning film critic Roger Ebert described the documentary as "an act of witness" that was among "the noblest films ever."17 Similarly, Richard Bernstein of the New York Times described Shoah as "(awakening) a new consciousness about the greatest evil of modern times."18 The critic Richard Brody, moreover, lauded Lanzmann's magnum opus as "instantly historic." 19 The renowned French existentialist and feminist philosopher Simone de Beauvoir, finally, described Shoah as a "sheer masterpiece."20

It ought to be noted that debating the Polish-Jewish past or exploring the legacy of antiSemitism in Poland were not necessarily the main motivations behind Lanzmann's film. On the

\footnotetext{
${ }^{16}$ Joanna Szczęsna, "25 lat sporów o 'Shoah,”, Gazeta Wyborcza, http://wyborcza.pl/2029020,76842,7694169.html.

${ }^{17}$ Roger Ebert, "Review of Shoah” http://www.rogerebert.com/reviews/great-movie-shoah-1985.

${ }^{18}$ Richard Bernstein, "Shoah (1985) an Epic Film about the Greatest Evil of Modern Times" The New York Times, http://www.nytimes.com/movie/review?res=9805E5DC1E39F933A15753C1A963948260.

${ }^{19}$ Richard Brody, "Witness: Claude Lanzmann and the Making of Shoah," http://www.newyorker.com/magazine/2012/03/19/witness-5?currentPage=all.

${ }^{20}$ Simone de Beauvoir, Preface to Claude Lanzmann, Shoah: An Oral History of the Holocaust: The Complete Text of the Film (New York: Pantheon Books, 1985), x.
} 
contrary, Shoah at its core sought to describe the Holocaust through the experiences of actual participants in the Holocaust-including both victims and victimizers. In order to get the latter perspective, Lanzmann often went to great lengths, including the extensive use of hidden cameras, which even resulted in his hospitalization following an assault by a former Nazi who was furious when he discovered he was being surreptitiously filmed. ${ }^{21}$ Shoah, ultimately, did not rely upon any historical footage; instead, Lanzmann reconstructed the memory of the Holocaust solely through his interviews with those who had first-hand experiences of the Shoah and by traveling to and filming the sites where the Holocaust actually occurred. ${ }^{22}$ In this manner Lanzmann hoped "to reincarnate" the tragic experiences of the millions of Jews systematically exterminated during the Second World War. ${ }^{23}$

Though Lanzmann did not necessarily intend to create controversy in Poland, it is not hard to see why his film angered many Poles. As De Beauvoir noted, the majority of Poles interviewed in the film appear indifferent to the fate of Jews or even satisfied by what transpired. ${ }^{24}$ Perhaps unsurprisingly, therefore, much of the debate in Poland focused not on the merits of the film but instead on how Lanzmann chose to portray Polish bystanders who witnessed the extermination of Polish Jews. ${ }^{25}$ To further complicate matters, the vast majority of Poles_-including many of Shoah's most vocal critics—never actually watched Lanzmann's film, and it was largely the Polish media's interpretation of the film that framed public opinion on the issue. $^{26}$ It has even been alleged that the Polish government asked François Mitterrand, France's

${ }^{21}$ Brody, "Witness," http://www.newyorker.com/magazine/2012/03/19/witness-5?currentPage=all.

${ }^{22}$ Bernstein, "Shoah,"

http://www.nytimes.com/movie/review?res=9805E5DC1E39F933A15753C1A963948260

${ }^{23}$ Ibid.

${ }^{24}$ De Beauvoir, Preface to Shoah, viii.

${ }^{25}$ Piotr Forecki, Reconstructing Memory: the Holocaust in Polish Public Debates (Peter Lang, 2013), 104.

${ }^{26} \mathrm{Ibid}, 105$. 
president at the time, to ban the film. ${ }^{27}$ Whatever the case, it is not difficult to imagine why the Polish state would have wanted to discourage the public from seeing Shoah, which would have made it even more difficult for ordinary Poles to seriously grapple with the issues brought to the forefront by Lanzmann's film. To make matters worse, Lanzmann made numerous troublesome claims in relation to the controversy that were widely publicized in the Polish media, which made serious reflection on the Holocaust and Polish-Jewish relations even less likely. For example, Lanzmann argued that anti-Semitism was a necessary feature of Catholicism and that the Third Reich had chosen Poland to carry out its genocidal plans because the Nazis knew that Poles would permit the extermination of Jews on their soil. ${ }^{28}$ Of course, such claims are deeply problematic to say the least, and it is easy to see why such controversial — and technically inaccurate - statements would further exacerbate the controversy. As a matter of fact, Poland was chosen as the primary site of the Nazi death camps because of the convenience of the country's vast Jewish population and because the Nazis wished to carry out the majority of their crime outside their own national borders. Similarly, while Catholic-Jewish relations are historically problematic, it is undoubtedly unfair to imply that all Catholics are anti-Semites.

Ultimately, Shoah's role in the Memory Wars is not entirely clear. While it is evident that the film engaged the issue of Polish complicity in the Holocaust, the opportunity for serious reflection on this issue was probably squandered. Still, Lanzmann's film posed an early challenge to the Polish memory of the Holocaust and spawned a multitude of angry responses from Polish intellectuals and from the Polish press. Undoubtedly, therefore, Shoah helped to get Poles engaged in these issues. While the discussion following the film's release was not exactly

\footnotetext{
${ }^{27}$ Brody, "Witness," http://www.newyorker.com/magazine/2012/03/19/witness-5?currentPage=all.

${ }^{28}$ Forecki, Reconstructing Memory, 105.
} 
nuanced, Shoah demonstrated how emotionally invested many Poles already were in debates over the Polish-Jewish past and the Holocaust. Lanzmann's film, moreover, provided a window into the attitudes of many Polish journalists and intellectuals' views on the legacy of antiSemitism in Poland and the question of Holocaust responsibility in the mid-1980s. Shoah likely failed to significantly alter attitudes in Poland, but Lanzmann's film helped to lay the foundations for future dialogue and debate on these issues.

\section{The Poor Poles Look at the Ghetto}

It would probably be hyperbolic to say that Jan Błoński, an eminent Polish historian and literary critic, fired the first shot in the Memory Wars; after all, there were undoubtedly numerous efforts to engage with the Polish-Jewish past within Poland that predated the publication of his seminal essay, "The Poor Poles Look at the Ghetto," which originally appeared in the Catholic magazine Tygodnik Powszechny in 1987. ${ }^{29}$ Nevertheless, Błoński’s article arguably represented the earliest and most serious attempt by a Polish scholar to argue for some degree of national responsibility and regret for the Holocaust. Indeed, unlike with Shoah, "The Poor Poles Look at the Ghetto" expressed the views of someone who truly understood Polish history and politics.

Błoński’s article takes its name from Polish Nobel laureate Czesław Miłosz’s poem “A Poor Christian Looks at the Ghetto," which is widely read as acknowledging Christendom's role in the slaughter of Jews during the Holocaust. ${ }^{30}$ Błoński's tone is deeply moralistic in his article.

\footnotetext{
${ }^{29}$ It ought to be noted that it is rather unsurprising that it was Tygodnik Powszechny, Poland's most independent legal magazine at the time, which published Błoński's article; Antony Polonsky, introduction to My Brother's Keeper?: Recent Polish Debates on the Holocaust, ed. Antony Polonsky (London: Routledge, 1990$)$, 10. 30 Ibid, 11.
} 
According to Błoński, remembering and interpreting what transpired during the Holocaust is an ethically and spiritually obligatory pursuit that cannot be allowed to disappear into the oblivion of forgetfulness. For Błoński, indeed, even unpleasant histories must always be confronted: "(Our country) is a home which is built above all of memory; memory is at the core of our identity. We cannot dispose of it at will, even though as individuals we are not directly responsible for the actions of the past. We must carry it within us even though it is unpleasant or painful. We must also strive to expiate it."31

For Błoński, however, history had failed to expiate this unpleasant past, and there was still much soul-searching to be done. While he acknowledged that historians had debated Polish anti-Semitism and the Holocaust with increasing sophistication and documentation, Błoński saw their arguments as part of a never-ending discussion, which he compared to an imaginary dialogue that was all too real for Poles who had traveled throughout the West. ${ }^{32}$ In this dialogue a Pole and an unidentified foreigner wrestle over the issue of the Polish-Jewish past. Why, the foreigner asks, had Poles been so intolerant toward Jews throughout history? And why had Poles not been able to envision a culturally and ethnically diverse Poland that included both Poles and Jews living together as neighbors? Finally, why had Poles not done more to save Jews during the Holocaust? For each of these questions posed to the hypothetical Pole, and for each additional question not listed here, an excuse is offered. Rather than embrace the dark past, the Pole offered nothing but endless rationalizations, but the troublesome history of Polish-Jewish relations, Błoński maintained, could not be dismissed with mere rationalizations. Instead, Poles were obligated to confront the Holocaust directly and embark upon a "moral revolution" that had

\footnotetext{
${ }^{31}$ Jan Błoński, “The Poor Poles Look at the Ghetto," My Brother's Keeper?, 35.

${ }^{32}$ Ibid, 37.
} 
the power to "cleanse (Poland's) desecrated soil.."33 In order to achieve this lofty goal, Błoński argued that Poles had to recognize their own ethical shortcomings during the Second World War and embrace their failure to come to the aid of Jews butchered by the Nazi regime. During the Holocaust, too many Poles had ignored the plight of their Jewish neighbors. And far too many Poles, Błoński alleged, had taken secret delight that Hitler had solved Poland's "Jewish problem" for them. ${ }^{34}$ And now he thought it was time to apologize to Jews around the world. For Błoński, ultimately, there was a deep problem with how Poles conceptualized the Holocaust and there was no doubt that Poles shared moral responsibility for the genocide. Nevertheless, Błoński disentangled shared responsibility from outright Holocaust participation, which he completely denied in his article. Błoński’s view was that Poles had turned their backs on Polish Jews, but they had not actually participated in any act of mass murder directly — a view that would later be repudiated by Jan Tomasz Gross when details of the Jedwabne pogrom came to light. ${ }^{35}$

Because Błoński’s article challenged Polish memory in such a profound way, it resulted in considerable controversy and debate. In fact, following the publication of "The Poor Poles look at the Ghetto," Tygodnik Powszechny received numerous letters in response to Błoński’s challenge — often with anti-Semitic undertones — that were far too vitriolic for publication. ${ }^{36}$ Władysław Siła-Nowicki, a lawyer famous for defending the political prisoners of the communist regime, remarked that Błoński’s article was the culmination of a "virulent anti-Polish propaganda campaign" that had been carried out by the enemies of the Polish nation. ${ }^{37}$ Siła-

${ }^{33}$ Ibid, 45.

${ }^{34}$ Ibid.

${ }^{35}$ Jan T. Gross, Neighbors: The Destruction of the Jewish Community in Jedwabne, Poland (Princeton University Press, 2001).

${ }^{36}$ Michael T. Kaufman, "Debate over Holocaust stirs passion in Poland," New York Times, March 8, 1987, http://www.nytimes.com/1987/03/08/world/debate-over-holocaust-stirs-passions-in-poland.html

${ }^{37}$ Władysław Siła-Nowicki, “A Reply to Jan Błoński,” My Brother’s Keeper?, 59. 
Nowicki was hardly alone with these views. Indeed, many Poles reacted with very similar sentiments. Witold Rymanowski, for example, argued that Błoński had slandered the Polish nation, a crime punishable by law, and characterized Błoński’s conclusion as “diabolically perverse." 38 Not all Polish intellectuals or journalists reacted with as much anger as Rymanowski or Siła-Nowicki. Consider, for example, Janina Walewska’s essay in response to the controversy, which also originally appeared in Tygodnik Powszechny. Walewska's views, like many Polish intellectuals, were deeply conflicted on the issue of Polish-Jewish relations. On the one hand, she understood — and was highly sympathetic toward - the views expressed by Błoński. On the other hand, she acknowledged that anti-Semitic attitudes had been deeply engrained in her consciousness all throughout her life, which made Błoński’s view a very difficult position to endorse wholeheartedly. Furthermore, Walewska maintained that Błoński was correct about the anti-Semitic nature of Poland both before and after the Second World War and that his critics like Siła-Nowicki were simply wrong when they tried to deny the extent of anti-Semitism in contemporary Polish society. ${ }^{39}$ Ultimately, Walewska argued, there was a genuine need for Poles to take collective responsibility for the fate of Polish Jews during the Second World War.

For shining a light on the importance of the Holocaust to the question of Polish-Jewish relations, Błoński and Lanzmann undoubtedly deserve credit. It is also quite clear that the debate over Błoński’s article was a crucial moment in the Memory Wars. Whereas Poles had previously reacted very defensively when troublesome questions about the Polish-Jewish past were brought to light, as in the case of Shoah, Błoński openly challenged the Polish memory of the Holocaust

\footnotetext{
${ }^{38}$ Witold Rymanowski, “The Disseminator of anti-Semitism? A Rejoinder to Jan Błoński," My Brother's Keeper?, 159.

39 Janina Walewska, “In a Sense I am an anti-Semite,” My Brother's Keeper?, 129.
} 
and demanded a reinterpretation of the dominant historical narratives that defined the Second World War and the Holocaust for the Polish public; nevertheless, because the readership of Tygodnik Powszechny was somewhat limited and because Błoński failed to consider actual Polish participation in the Holocaust, the debate over "The Poor Poles Look at the Ghetto" remained confined to a relatively small part of the Polish population, namely, the intelligentsia. With that said, both Shoah and "The Poor Poles Look at the Ghetto" had helped to confirm the importance that debates over the Polish-Jewish past had for Poland's intelligentsia during the 1980s. These debates, however, were still very much in their infancy. When they would reach their crescendo, it would shake the moral foundations of post-communist Poland like nothing before or since. But the debates over Shoah and "The Poor Poles Look at the Ghetto" were not the only controversies that were beginning to unravel Polish national memory. While these debates were taking place, another challenge was posed - this time over the meaning of Auschwitz.

\section{Remembering Auschwitz}

In the decades following the Second World War, Auschwitz has emerged as the ultimate symbol of the Holocaust. This is true even though the majority of Jewish Holocaust victims did not necessarily perish at death camps like Auschwitz; instead, roughly half of all Jewish victims were gunned down with bullets in the so-called Bloodlands. ${ }^{40}$ But this history has a tendency to be superseded by the horrors of the death camps. Indeed, when the Holocaust is depicted in popular media, there is often an emphasis on concentration camp experiences and much of the

\footnotetext{
${ }^{40}$ Timothy Snyder, Bloodlands: Europe Between Hitler and Stalin. (New York: Basic Books, 2010).
} 
imagery presented comes directly out of (but is by no means unique to) Auschwitz. Consider, for example, the frequent depictions of the infamous Arbeit Macht Frei sign, images of trains crossing under the main arch at the gate of Auschwitz-Birkenau, the notorious gas chambers designed to look like showers, the crematoria, the omnipresent hunger and extreme suffering that characterized daily life, or the piles of emaciated corpses discovered by Soviet troops.

Ultimately, the egregious nature of concentration camp life dominates the memory of the Holocaust, and no single concentration camp has impacted public consciousness as much as Auschwitz.

Because of the extremely traumatic nature of this history, it should come as no surprise that Auschwitz - a place where over one million Jews were systematically slaughtered by the Third Reich — has come to be seen as a site of sacred memory for Jews. Indeed, Auschwitz represents the nadir of Jewish historical memory and a disturbing reminder of genocide. Perhaps equally important, however, Auschwitz has come to symbolize the dangers of anti-Semitism and the importance of overcoming the past. During a trip to Poland in 2010, for example, Israeli Prime Minister Benjamin Netanyahu explained the importance of memory during a speech at Auschwitz: "I have come here today from Jerusalem to tell you: We will never forget. We will not allow the Holocaust deniers or those who desecrate [Jewish] graves and signs to erase or distort [our] memory... Murderous hatred must be stopped in its tracks, stopped right from the beginning. All countries in the world must learn this lesson, just as we did after losing a third of our people in blood-soaked Europe."41 Such commentary, of course, must be interpreted within the context of the contemporary Arab-Israeli conflict and is undoubtedly motivated by a desire to

\footnotetext{
41 "Netanyahu at Auschwitz: Never again," last modified January 27, 2010, http://www.jpost.com/International/Netanyahu-at-Auschwitz-Never-again
} 
legitimate the Israeli military's occupation of Palestinian territories in the West Bank and the Gaza Strip. With that said, the fact that Netanyahu chose Auschwitz as a site to deliver such a message carries symbolic weight and highlights its importance within Jewish collective memory.

Like many memorials, Auschwitz has at times emerged as a site of contested memory. Indeed, many Poles also view Auschwitz as a sacred national site. Of course, this attitudemuch like the Jewish claim to Auschwitz - is undoubtedly well grounded in the facts of history. There is no denying that Poles were also victimized by the Nazis. In fact, Auschwitz I was initially constructed for Polish political prisoners, and ultimately around seventy thousand Poles perished at the Auschwitz death camps. Moreover, Poland found itself at the crossroads of both Soviet and Nazi terror during the war, and the country suffered traumatically as a result. ${ }^{42}$ Nevertheless, it is also undeniably true that there exists an asymmetry between Polish and Jewish suffering during the war and that Jews were targeted for extermination in a much more deliberate manner than Poles. Despite this asymmetry, in the decades following the Second World War, Auschwitz emerged as the primary public space where Poles commemorated their wartime dead. ${ }^{43}$ Auschwitz, indeed, was used by Poles to memorialize their own suffering during the war within a nationalistic framework. During the communist years, the suffering of other national groups, by contrast, was placed within an international Marxist-Leninist framework. ${ }^{44}$ Needless to say, this representation necessarily deviated from the historical experiences and the memory of Jews.

\footnotetext{
${ }^{42}$ For a transnational discussion that covers both Soviet and Nazi terror in Poland, see Snyder, Bloodlands. For an account that focuses exclusively on the Nazi assault, see Alexander B. Rossino, Hitler Strikes Poland: Blitzkrieg, Ideology, and Atrocity (Lawrence: University Press of Kansas, 2003).

43 Jonathan Huener, Auschwitz, Poland, and the Politics of Commemoration, 1945-1979 (Athens: Ohio University Press, 2003), 3.

44 Ibid.
} 
This struggle over the memory of Auschwitz — and its historical meaning — arguably first entered public discourse with the Carmelite convent controversy, which brought to the forefront the vexing issue of Polish-Jewish relations. Essentially, the debate was ignited when a group of nuns from the Order of Our Lady of Mount Carmel moved into the Theatergebäude, which was the Old Theater building right outside Auschwitz I, in 1984. This building had also been used by the Nazis to store Zyklon B during the Holocaust. This action, which was permitted by the Polish government, was evidently undertaken without consulting any Polish Jews or Jews living outside Poland. ${ }^{45}$ This decision elicited anger from many Jews around the world. In response to the controversy over Auschwitz, Yitzhak Shamir, who was at the time Prime Minister of Israel, infamously remarked in 1989 that "(Poles) suck (anti-Semitism) in with their mother's milk."46 Despite the considerable outcry, the nuns remained steadfast in their resolve. The convent's superior, Sister Maria Teresa, for example, reportedly said in a 1989 interview that the Carmelites would not be "moving a single inch." 47 In the end, however, the Carmelites would be forced to move, but it was not until 1993 when Pope John Paul II ordered the remaining nuns to leave the convent in a letter. ${ }^{48}$

Many Catholic Poles condemned Jews who called for the closure of the Carmelite convent, and some prominent Polish clergy even made explicitly anti-Semitic remarks when discussing the controversy. In a 1989 sermon, for instance, Józef Cardinal Glemp reportedly claimed that Jews controlled the media and also argued that Jews were somehow culpable for the spread of alcoholism across Poland. ${ }^{49}$ Additionally, Glemp, who was also the Archbishop of

\footnotetext{
${ }^{45}$ Carol Rittner and John K. Roth, eds., Memory Offended: The Auschwitz Convent Controversy (New York: Praeger, 1991), 20-21.

46 "Poles born anti-Semitic, Shamir says," Globe and Mail, September 9, 1989.

${ }^{47}$ Rittner and Roth, Memory Offended, 25.

48 Jane Perlez, "Pope Orders Nuns out of Auschwitz" New York Times, April 15, 1993.

49 Robert D. McFadden, “Glemp Pledges Better Interreligious Ties” New York Times, October 7, 1991.
} 
Warsaw at the time, made the controversial claim that a small group of Jewish protestors in 1989 would have killed the nuns of the convent had their protest not been stopped.$^{50}$ Of course, those involved in this protest vehemently reject this accusation. The Rabbi Avraham Weiss, who was the protestors' leader, has said that the group was quite shocked to be characterized as militants in the media and claimed that they had no violent intent whatsoever. ${ }^{51}$ Rabbi Weiss also claimed that the small group crossed the convent's fence only after their attempts to open a dialogue with the nuns were ignored. ${ }^{52}$ Moreover, their demonstration consisted solely of wrapping themselves in prayer shawls and reading and reciting the Torah on the convent's porch, but workers within the convent responded to their peaceful protest by dumping buckets of water mixed with urine and paint on the group. After this strategy failed to convince the protestors to leave, those same workers later returned, punching, kicking and attempting to drag the protesters off the convent's grounds. One worker reportedly shouted, "Heil Hitler!" 53

Of course, there were also Polish Church leaders who attempted to take steps toward Jewish-Christian dialogue in the midst of the controversy. Pope John Paul II, for example, condemned anti-Semitism, referring to it as a "sin against God and humanity" in $1990 . .^{54}$ Additionally, on January 20, 1991 a pastoral letter was read in every Catholic church across Poland that acknowledged a troublesome history and expressed "sorrow for all the injustices and harm done to Jews." ${ }^{55}$ While this letter made some effort to address the problems that the Auschwitz controversy had brought to the surface, the letter rejected the notion that there was

\footnotetext{
50 Ibid.

${ }^{51}$ Rabbi Avraham Weiss, "Let the Nuns Pray Elsewhere," October 5, 1989, in Memory Offended, 255-56.

${ }^{52}$ Ibid, 256.

${ }^{53}$ Ibid.

${ }^{54}$ Rittner and Roth, Memory Offended, 26.

55 Ibid.
} 
anything unique about Polish anti-Semitism. ${ }^{56}$ Furthermore, the letter emphasized that Poles were the first victims of the Nazis and celebrated Polish heroism during the war. ${ }^{57}$ There also was no mention of Polish collaboration or participation in the Holocaust - that conversation would have to come later. With all that said, while this letter did not represent a major step toward reconciliation, it still nevertheless demonstrated an attempt at confronting the past in some small way. Furthermore, as the result of a February 1987 agreement between Jewish and Catholic leaders, an interfaith center was eventually established to replace the convent. This center, which is known as the Centre for Dialogue and Prayer in Oświęcim, was created in part to be a "place of dialogue between people and nations of various cultures and religious beliefs." 58 Fortunately, the Carmelite convent controversy was resolved, and the establishment of the Auschwitz interfaith center was an important early step for Polish-Jewish relations, but it must be emphasized that this was largely established through a dialogue between Polish and Jewish religious elites, and it was at least partially the result of considerable international pressure. The Polish general public, it must be emphasized, was simply not yet prepared to deal with the deeply troublesome history of anti-Semitism in Poland.

Unfortunately, the debate over Auschwitz was reignited in 1998 when the Polish government announced that a large cross outside Block 11, which had been erected by the Carmelites before they had been forced to vacate the convent, was going to be removed. In response to this perceived provocation, Polish ultranationalists placed hundreds of smaller crosses just outside the grounds of Auschwitz in protest, which surprised and angered Jews around the world. This renewed controversy over the memory of Auschwitz has been referred to

\footnotetext{
56 Polish Pastoral Letter, November 30, 1990, "Pastoral on Jewish-Catholic Relations," in Memory Offended, 266.

57 Ibid, 265-66.

58 “Centre for Dialogue and Prayer in Oświęcim,” accessed March 27, 2015, http://www.cdim.pl/en.
} 
as the War of the Crosses. ${ }^{59}$ Essentially, this second debate began when Krzysztof Śliwiński announced in an interview with La Croix, a Catholic newspaper based in France, that the Auschwitz cross - referred to by many of its supporters as the "papal cross" because it was originally constructed for a special mass following Pope John Paul II's historic election ${ }^{60}$ would be removed just as the Carmelite convent had been removed five years earlier. ${ }^{61}$ Śliwiński, for his part, was already prominent in the discussion over Polish-Jewish relations. Indeed, during the communist era, Śliwiński had organized various Jewish cemetery cleanups and had participated in numerous other pro-Jewish initiatives. In 1995, moreover, he was appointed Poland's first post-Communist ambassador to the Jewish diaspora by Wladyslaw Bartoszewski, who was Foreign Minister at the time. ${ }^{62}$ But Śliwiński's comments were met with great opprobrium — especially from those engaged in far-right, nationalistic politics. Antoni Macierewicz, for example, characterized Śliwiński’s proposal as a "national humiliation."'63 Ultimately, over 130 deputies and right-wing senators signed a petition calling for the cross's preservation. ${ }^{64}$ Even Lech Wałęsa, co-founder of Solidarność and Poland's second postcommunist President, sided with the supporters of the so-called papal cross in a letter to Bishop Tadeusz Rakoczy. ${ }^{65}$ Another former Solidarność activist, Kazimierz Świtoń, took matters even

${ }^{59}$ Geneviève Zubrzycki, The Crosses of Auschwitz: Nationalism and Religion in Post-Communist Poland (University of Chicago Press, 2006), 3.

${ }^{60}$ It ought to be noted that the term "papal cross" is misleading since the cross was neither blessed by the Pope nor given any special religious significance by the Vatican; Janine P. Holc, "Memory Contested: Jewish and Catholic Views of Auschwitz in Present-Day Poland," in Antisemitism and its Opponents in Modern Poland, ed. Robert Blobaum (Ithaca: Cornell University Press, 2005), 308.

${ }^{61}$ Zubrzycki, The Crosses of Auschwitz, 8.

${ }^{62}$ Ruth Ellen Gruber, “At last, Warsaw’s Museum of the History of Polish Jews is dedicated,” April 18, 2013,http://www.jewishjournal.com/culture/article/at_last_warsaws_museum_of_the_history_of_polish_jews_is_de dicated

${ }^{63}$ Zubrzycki, 8.

${ }^{64}$ Ibid, 8-9.

${ }^{65}$ Ibid. 
further by declaring that he would go on a hunger strike until the Catholic Church gave its assurances that the cross would not be removed. ${ }^{66}$

The War of the Crosses was not simply a controversy confined to the ivory tower. Nor was it simply an issue for religious and political elites. Instead, the debate's significance was recognized by a large section of the Polish public_-some of whom even came to Auschwitz as pilgrims during the summer of 1998. Some of these pilgrims were simply curious tourists. Others were journalists looking for a provocative story. And, of course, some were committed nationalists who were determined to defend the notion of a uniquely Catholic Poland. ${ }^{67}$ Perhaps unsurprisingly, therefore, prayer vigils and masses were regularly held outside Auschwitz, and nationalist symbols — such as the Polish flag and the Polish coat of arms - were prominently displayed during their protests alongside religious symbols. ${ }^{68}$ Within Poland, there has long been a close relationship between Catholicism and national identity. This relationship is enormously complex and is the product of a long historical relationship. While there was definite hostility between the Church and the Polish nationalist movement in the nineteenth century, there was a clear reconciliation in the early years of the twentieth century; indeed, within a few decades, many Poles had embraced the view that a Pole was necessarily Catholic and that Catholicism was the bedrock of the nation's moral and spiritual values. ${ }^{69}$ During the interwar years, moreover, Catholicism was synthesized with Polish national identity in such a way that Poles were placed at the top of a racial and cultural hierarchy, whereas Jews were located at the bottom. ${ }^{70}$ This process undoubtedly reinforced anti-Semitic attitudes and

\footnotetext{
${ }^{66}$ Ibid, 9-10.

${ }^{67}$ Ibid, 10.

${ }^{68}$ Ibid.

${ }^{69}$ Brian Porter-Szücs, Faith and the Fatherland: Catholicism, Modernity, and Poland (Oxford University

70 Zubrzycki, 57.
} Press, 2011), 208. 
contributed to a politics of exclusion where Jews were defined as existing outside the normal social and political order. This was certainly not a phenomenon that was unique to Poland. In fact, the Catholic Church itself has a long history of cultivating anti-Semitism across Europe. ${ }^{71}$ Ultimately, the convergence of traditional Catholic anti-Semitism—or Judeophobia—with Polish national identity created an atmosphere that was deeply troublesome for Jews. Thus, given the historical experiences of post-communist Poland, which was still a country in transition that was desperate to reclaim its national independence and identity after five decades of Soviet hegemony, it is not hard to see why the War of the Crosses would strike such a nerve among the Polish public.

The crisis of 1998 was partially resolved when the Polish government agreed to remove the myriad crosses placed by the ultranationalists. The so-called papal cross, however, was not removed, and it remains there to this day. For many Jews the presence of Christian religious symbols at Auschwitz is intolerable and distorts the memory of the Holocaust. Many Poles, by contrast, view Auschwitz as a legitimate part of their history and feel that any attempt to remove Catholic influence from Auschwitz represents an effort to exclude Poles from a site that is of paramount importance to their historical memory as well. This is undoubtedly a complex issue. Nevertheless, it is surely true that one can recognize the undeniable historical reality that Poles suffered horrendously during the war-including at Auschwitz - without the presence of explicitly Christian symbols at the death camps.

Ultimately, both the Auschwitz convent controversy and the War of the Crosses brought to the forefront numerous issues at the heart of Polish-Jewish relations and the memory of the

\footnotetext{
${ }^{71}$ See, for example, David I. Kertzer, The Popes Against the Jews: The Vatican's Role in the Rise of Modern Anti-Semitism (New York: Alfred A. Knopf, 2001).
} 
Second World War. These debates forced Poles to ask questions that were not necessarily discussed at length during much of the communist era. Who, for instance, were the true victims of Auschwitz? How should both Jewish and Polish suffering during WWII be characterized? And additionally, what does it mean to be Polish? And how has Polish identity related to the historical presence of Jews in Poland? With these controversies, it is evident that the Memory Wars were very much underway in Poland. But one of the central dogmas of Polish memory of the Second World War — namely, the narrative of victimization — was about to be challenged in an even more profound way with the publication of Gross's Neighbors. 


\section{Chapter Three: The Neighbors Controversy}

All too frequently nations have a tendency to obscure or marginalize the most shameful episodes of their history. The worst tragedies are sometimes forgotten entirely, but what happens when these tragedies resurface? What happens, indeed, when a national memory is confronted by unpleasant truths which it cannot accommodate without serious tension? Such questions cannot be answered in the abstract. They must be explored on a case-by-case basis. Fifteen years ago, Poland faced this dilemma when Jan Tomasz Gross, now a Professor of History at Princeton University, published Neighbors: The Destruction of the Jewish Community in Jedwabne, Poland in 2000. The publication of Gross's book sparked national soul-searching and extensive debate. This controversy would place the town of Jedwabne at the center of public attention, and it would generate a massive literature and a multitude of attempts to make sense of the revelations presented in Gross's book.

First, in order to understand why Gross's book was so controversial, some brief historical background is necessary. In 1939 the Soviet Union agreed to a non-aggression pact with Nazi Germany, which would come to be known as the Molotov-Ribbentrop Pact. This agreement contained a secret protocol calling for the division of Central and Eastern Europe along German and Soviet spheres of influence. On September 1, 1939 Nazi Germany invaded Poland, triggering the Second World War. The USSR, determined to stake its claim to the territory the Nazis had agreed to recognize as part of its sphere of influence, invaded Poland from the east sixteen days later. The small town of Jedwabne, which contained a large population of Jews and Poles living together as neighbors, thus found itself under Soviet occupation. On June 22, 1941 Hitler launched Operation Barbarossa, a massive assault on the Soviet Union. The Soviets were quickly forced back, and the town of Jedwabne then changed hands and fell under Nazi 
occupation. Next, something shockingly atrocious happened: the Polish inhabitants of the town slaughtered their Jewish neighbors. Many, indeed, were forced into a barn and burned alive. Prior to the publication of Neighbors, this disturbing incident had been largely forgotten by historians and other scholars. ${ }^{72}$

Because Poles had previously been presented solely as victims, Gross's book thus challenged the dominant post-war historical narrative in Poland. According to this representation of the past, it was ultimately the Nazis - and later the Soviets too, but not until communism in Poland came to an end ${ }^{73}$ — who were the real perpetrators of all the war's carnage. They alone were responsible for the unprecedented, nihilistic violence that characterized the war. This myth of victimization went beyond the mere belief that many Poles were victims during the Second World War. Contesting that claim would be absurd, of course. The myth of victimization, however, was a nationalist myth that either granted primacy to Polish suffering during the war or presented both Polish and Jewish experiences of the Second World War as being equivalent. Gross's book, by contrast, offered a clear challenge to this Polish claim of victimhood. Indeed, Neighbors ultimately suggested that Poles were not just victims; nor were they simply collaborators. Instead, they were sometimes active, enthusiastic participants in the Holocaust. Neighbors was quite popular in the United States and was even named a finalist for the National Book Award. The reception of Neighbors was much more complex in Poland,

72 Jan T. Gross, Neighbors: The Destruction of the Jewish Community in Jedwabne, Poland (Princeton University Press, 2001); Gross's book first appeared in Polish with the title Sasiedzi: Historia zagłady zydowskiego miasteczka (Sejny, 2000). It was partially inspired by Gdzie mój starszy syn Kain?, or Where is My Older Son Cain?, which was a documentary produced by Agnieszka Arnold.

${ }^{73}$ For an example how the communist state repressed memory in Poland, see Witold Wasilewski, "The Birth and Persistence of the Katyn Lie," Case Western Reserve Journal of International Law 45 (2013). 
however. This should come as no real surprise given Gross's challenge to Polish memory. Perhaps unsurprisingly, his book led to a firestorm of controversy throughout Poland.

\section{Debate among Scholars and in the Polish Press}

Before exploring the diverse responses to the Neighbors controversy, it is necessary to point out that many scholars have challenged the core ideas and conclusions in Gross's book. For example, many Polish scholars argued that Gross seriously underestimated Nazi participation in the destruction of Jedwabne's Jewish community. Others questioned whether or not Gross oversimplified what happened at Jedwabne and jumped to conclusions based on limited evidence. Perhaps the most serious attack on Gross's arguments came from Marek Jan Chodakiewicz in his book The Massacre in Jedwabne, July 10, 1941: Before, During, After. Indeed, Chodakiewicz set out to refute many of Gross's conclusions and to expose "the many methodological and factual weaknesses of Neighbors." ${ }^{.74}$ Other historians have launched similar assaults on Gross and Neighbors. Bogdan Musiał, for example, attacked Gross's methodology and his use of sources. ${ }^{75} \quad$ Musiał also doubted the death toll proposed in Neighbors and criticized Gross for allegedly being uncritical about the figure he accepted. ${ }^{76}$ The literature debating the merits of Gross' conclusions is often very polemical, and many authors have gone to great lengths to discredit Gross. Many of these arguments are deeply troublesome. Tomasz Strzembosz, for example, claimed that Gross underestimated the widespread Jewish support for the USSR when the Soviets invaded Poland and argued that this should alter the way the events

\footnotetext{
${ }^{74}$ Marek Jan Chodakiewicz, The Massacre in Jedwabne, July 10, 1941: Before, During, After (Boulder, Co: East European Monographs, 2005), 4.

${ }^{75}$ Bogdan Musiał, "The Pogrom in Jedwabne: Critical Remarks about Jan T. Gross's Neighbors," in The Neighbors Respond: The Controversy over the Jedwabne Massacre in Poland, ed. by Antony Polonsky and Joanna B. Michlic (Princeton: Princeton University Press, 2004), 304.

${ }^{76}$ Ibid, 324-326.
} 
at Jedwabne are remembered. ${ }^{77}$ Strzembosz was quick to acknowledge that nothing justifies mass murder, but his account did present Jews as traitors "who staged a mass welcome for the (Red Army) and took part in introducing the new order." ${ }^{, 78}$ Strzembosz may have wanted to distance himself from a defense of mass murder, but it is hard to see what point he was making by emphasizing Jewish collaboration with the Soviets—unless, of course, his essay is viewed as an attempt to minimize the seriousness of the crime against Jedwabne's Jewish population or as an attempt to justify Polish anti-Semitism. Furthermore, as a general rule, when an author has to qualify his remarks at the beginning of an essay in order to explicitly reject an act of such extreme, deadly brutality, this usually means that what follows is likely to be problematic to say the least.

Many critics responded to Gross's book with even more vitriol than Strzembosz, however. Antoni Macierewicz, for instance, maintained that Gross had embarked upon a "hate campaign" and a "propaganda war" against Poland and Poles with the publication of Neighbors. ${ }^{79}$ Macierewicz also adopted a conspiratorial perspective in his writings on the controversy. Because the Kielce pogrom had been shown - to Macierewicz's satisfaction at least - to have been merely a crime by the NKVD and the UB, i.e. the Soviet and Polish security services respectively, he argued that those who hated Poland chose to adopt Jedwabne as the new instrument to propagate the "myth" of Polish anti-Semitism. ${ }^{80}$ This conspiratorial perspective was also endorsed, for example, by the aforementioned Cardinal Józef Glemp, who even suggested that someone had ordered Gross to write and publish Neighbors. ${ }^{81}$ Ultimately,

\footnotetext{
77 Tomasz Strzembosz, "Collaboration Passed Over in Silence," in The Neighbors Respond, 220-236.

${ }^{78}$ Ibid, 220-221, 224-225.

${ }^{79}$ Antoni Macierewicz, "The Revolution of Nihilism," in Thou Shalt Not Kill: Poles on Jedwabne, ed. by William Brand (Warsaw: Więź, 2001), 207.

${ }^{80} \mathrm{Ibid}, 206$.

${ }^{81}$ Piotr Forecki, Reconstructing Memory, 189.
} 
Macierewicz's interpretation suggested that Gross and his supporters were nothing more than anti-Polish cynics who were willing to use any tool possible to discredit Polish history. Others, such as Ryszard Bender and Jerzy Robert Nowak, also responded to the controversy with quite radical views. ${ }^{82}$ Though it is crucial to distinguish between Gross's critics, many authors displayed anti-Semitic arguments and rhetoric in their responses to Neighbors-even many of those who have acknowledged some degree of Polish participation in the Jedwabne pogrom. ${ }^{83}$

It is necessary to point out that there were also more balanced, diplomatic responses offered to Neighbors. A good example of this can be found in Dariusz Stola's essay "Jedwabne: How was it Possible?" Pointing out that the discipline of history routinely makes progress on the basis of revision and argument, Stola praised Gross for setting in motion a new discussion on Polish-Jewish relations and the Jedwabne pogrom. ${ }^{84}$ With that said, Stola recognized that there are legitimate questions raised by Gross's critics; nevertheless, those critics cannot simply dismiss Gross's contribution to the discussion over Poland's past. ${ }^{85}$ Ultimately, it was necessary to balance some of the more antagonistic, inflammatory responses with more open and honest analyses. Since this has now happened, a deeper dialogue among scholars and a better understanding of the significance of the revelations provided by Gross is now possible. As Polonsky and Michlic have pointed out, articles such as Stola's reflect a shift in the tone in which these debates have taken place. ${ }^{86}$ This is largely the result of a tremendous awareness of Jedwabne and the Neighbors controversy among Polish historians and other scholars. The

${ }^{82}$ Ibid, 178.

${ }^{83}$ Ibid.

${ }^{84}$ Dariusz Stola, “Jedwabne: How was it Possible?" in The Neighbors Respond, 386.

${ }^{85}$ Ibid.

${ }^{86}$ Polonsky and Michlic, "Introduction to 'Part VI: Memories and Methodologies: The Historical Debate," in The Neighbors Respond, 219. 
academic discussion over Jedwabne, ultimately, has progressed considerably since the publication Gross's book in 2000.

There were also many scholars and journalists who more or less sided with Gross against his critics and stressed the importance of understanding Gross's revelations. Consider, for instance, the response offered by Jan Nowak- Jeziorański, a prominent émigré Polish journalist, war hero, and former chief of the Polish desk at Radio Free Europe, in his article "A Need for Compensation.” Nowak-Jeziorański argued that much of what was initially debated was misguided on some level. The central issue, he maintained, is not the motivation of those who slaughtered Jedwabne's Jews, or whether Gross had misread his sources, left out important information, or overestimated the number of individuals killed. On the contrary, the essential point was the "undeniable fact that old people and children, men and women, were murdered in Jedwabne in an unbelievably brutal manner at the hands of Poles." 87 Nowak-Jeziorański then proclaimed, "Attempts to undermine this fundamental assertion are, in light of the evidence presented, nothing but a denial of the truth." 88

These are undoubtedly interesting claims. If Nowak-Jeziorański is correct, these statements reveal that much of the existing historiography fails to address satisfactorily Gross's real challenge to Polish national mythology. Arguably, within the context of memory studies, the most interesting part of the Neighbors dispute is its impact on Polish conceptions of history and Polish-Jewish relations. Interestingly, however, Nowak-Jeziorański also expressed concern for the impact of Neighbors on Poland's image abroad, fearing that the book would reinforce

\footnotetext{
${ }^{87}$ Jan Nowak-Jeziorański, “A Need for Compensation,” in Thou Shalt Not Kill: Poles on Jedwabne, ed. by William Brand (Warsaw: WIĘŹ), 157.

${ }^{88}$ Ibid.
} 
stereotypes that all Poles were anti-Semites. ${ }^{89}$ This captures an important part of much of the resistance to Gross's book, and it also demonstrates that the dispute's impact on collective memory may extend beyond Poland. The fear, indeed, was that Gross's account presented a damning portrayal of Poland that would mislead outsiders. Perhaps unsurprisingly, for many authors this led to a rejection of Gross's work. Much of the dispute's intensity, as NowakJeziorański helped to elucidate, was thus largely connected to Neighbors being perceived as an attack on Polish national pride — especially by those on the political right.

Another fascinating article to consider is Jerzy Sławomir Mac's "Homo Jedvabicus" published in 2001. Mac used the term Homo Jedvabicus to refer to those who did not want to confront the unpleasant truths about the Jedwabne massacre that Gross had brought to the forefront. Such individuals, Mac argued, were characterized by "spinelessness, hypocrisy, an ostrich-like inclination to stick one's head in the sand, a hysterical fear of unpleasant truths, and an inability to cope with the challenge of shattering the myths of Poles as suffering and heroic during the Second World War."90 This is, of course, a harsh assessment, but it suggests just how high the stakes truly were in Mac's mind. Mac additionally argued that there was a new metaphorical Polish inferno, which could be conceived as a threat to Poland's reputation and its relationship with Jews, that the Homo Jedvabicus was indifferent toward. ${ }^{91}$ Once again, this shows the morally charged nature of the Neighbors controversy. This was, indeed, an issue that captured people's attention and required urgent public discussion. It was not merely an academic dispute but one that touched upon themes relevant to Polish collective memory and national responsibility much more generally.

\footnotetext{
${ }^{89}$ Ibid, 160.

90 Jerzy Sławomir Mac, "Homo Jedvabicus," in The Neighbors Respond, 115.

${ }^{91}$ Ibid, 118.
} 
An article published by the Polish sociologist Hanna Świda-Ziemba also sought to explore some of the implications of Neighbors. For Świda-Ziemba, indeed, much like for Nowak-Jeziorański, a number of the key elements that appeared early on in the debate were simply not all that important. Pinpointing, say, the precise role of the Nazis or figuring out the exact number of Poles who participated in the massacre simply could not alter the simple, unalterable fact that the crime was committed by the local population. ${ }^{92}$ She furthermore pointed out the important role that prejudice played in instigating the massacre, denying that there was a gulf between anti-Semitism and the crime committed at Jedwabne. ${ }^{93}$ The revelation about the slaughter of Jews offered by Gross, moreover, led Świda-Ziemba to conclude that antiSemitism was deeply rooted in Polish society. ${ }^{94}$

Ultimately, argued Świda-Ziemba, Poland was morally obligated to engage with this dark, troublesome episode in Poland's past. In the aftermath of Neighbors, Polish anti-Semitism would have to be viewed through the prism of Jedwabne, which would demonstrate the danger of anti-Semitism if it went ignored. Additionally, she maintained, the Sejm-i.e., the Polish parliament — ought to unambiguously condemn the massacre, and she argued that the "shock" of Jedwabne had the potential to present a new kind of "self-knowledge."95 This shows that, even very early on, observers were taking note of the importance of the Neighbors controversy and its potential to reshape Polish-Jewish relations. It is worth pointing out also that Świda-Ziemba understood that this self-knowledge and overturning of the myths of the past would not have been possible without Gross's book. That is not to say that Neighbors somehow made the reshaping of Polish memory inevitable. Instead, the point is that this was a key moment in

\footnotetext{
${ }^{92}$ Hanna Świda-Ziemba, "The Shortsightedness of the 'Cultured,'” in The Neighbors Respond, 103.

93 Ibid, 105.

94 Ibid, 107.

95 Ibid, 112-113.
} 
Polish history, barely a decade after the collapse of communism, in which the myths of Poland's past could be openly questioned. Gross's Neighbors thus came at the right time with the right message.

\section{Official Commemoration}

Compared to the earlier battles in the Memory Wars, the Neighbors controversy engendered the most significant and longest lasting public debate. It was so large, in fact, that many prominent Polish political figures felt obligated to address the controversy. Perhaps the most significant of these statements was the public apology delivered by Aleksander Kwaśniewski, the President of Poland from 1995 to 2005, during a ceremony marking the sixtieth anniversary of the Jedwabne massacre in 2001. Of course, it is revealing in itself that an anniversary was being held so soon after the publication of Gross's book and that this anniversary included an official apology from a head of state. For Kwaśniewski it was apparent that an egregious crime had been committed against Jedwabne's Jewish population. Indeed, Kwaśniewski acknowledged that Jedwabne's Jews were ruthlessly slaughtered. It is also important to recognize that Kwaśniewski expressed no doubt that Poles were involved in this slaughter. Moreover, the debate surrounding the Jedwabne pogrom, Kwaśniewski argued, was occurring during an important moment in Polish history and represented a pivotal shift in Polish attitudes. "Today's Poland," Kwaśniewski boldly proclaimed, "has the courage to look in the eye the truth about the nightmare that darkened one of the chapters of her history." 96 Those who deny this past, Kwaśniewski added, lead the nation toward "moral self-destruction."97

\footnotetext{
${ }^{96}$ Address by President of Poland Aleksander Kwaśniewski at the Ceremonies in Jedwabne Marking the Sixtieth Anniversary of the Jedwabne Tragedy on 10 July 2001" in The Neighbors Respond, 131.

${ }^{97}$ Ibid.
} 
From such comments it is more than apparent that in Kwaśniewski's mind the stakes were enormous. The debate over Jedwabne was not an inconsequential issue confined to Poland's past. On the contrary, addressing this dark and troublesome history was an urgent and immediate problem for Poland in the present. Gross had revealed that Poles had taken part in a terrible crime, and Kwaśniewski felt that an official apology on the sixtieth anniversary of the slaughter of Jedwabne's Jews was morally necessary for Poland's redemption. Kwaśniewski hoped not just for redemption, however. He also thought that, through commemoration and an honest examination of the past, Jedwabne could "become a place of reconciliation."98 Thus, Kwaśniewski hoped that the discussion of the pogrom could fundamentally reshape PolishJewish relations. In order for this to happen, however, he noted that one must first accept the truth about what really occurred at Jedwabne. Denying past realities-especially those that are extremely upsetting and disturbing — could not be regarded as a viable option for Poland in Kwaśniewski's mind. The past had to be dealt with. Only confronting the truth in all its unpleasantness, he argued, could allow for the "cleansing of memory's wound." 99

It is interesting to note that Kwaśniewski would not be the last Polish President to apologize for the Jedwabne massacre. Just ten years later, during the 70th anniversary of the pogrom, Bronisław Komorowski, Poland's current President, reiterated the sentiments expressed by Kwaśniewski and asked the Jews again for their forgiveness. ${ }^{100}$ It is undoubtedly revealing that two Polish presidents over the course of a single decade felt the need to apologize for the Jedwabne pogrom. This is a testament to the impact of the debate provoked by Gross and the

${ }^{98}$ Ibid, 132.

99 Ibid.

100 "Poland asks Jews for forgiveness on 70th anniversary of Yedvabne massacre," Haaretz, http://www.haaretz.com/print-edition/news/poland-asks-jews-for-forgiveness-on-70th-anniversary-of-yedvabnemassacre-1.372579. 
extra symbolic weight that the issue has taken on. Furthermore, this suggests a serious commitment on the part of the Polish state to overcome the country's troublesome past. Rather than ignore or marginalize the issue, the Polish government has felt pressured to confront the country's history in a very direct manner on at least two separate occasions.

Another important political figure who offered an interesting statement on the controversy surrounding Jedwabne is Władysław Bartoszewski, the aforementioned former Polish Minister of Foreign Affairs and a former Auschwitz survivor himself who had been arrested by the Germans during the war for his resistance activities, which included the organization of aid to Jews seeking to escape Nazi persecution. Indeed, Bartoszewski delivered a speech at the Holocaust Memorial Museum in Washington, DC on April 5, 2001, announcing that his country could attain "moral greatness" through confronting the past. ${ }^{101}$ In order to achieve this, argued Bartoszewski, Poland would have to follow the model set by the United States with regard to its role in Vietnam and deal with its past extensively through films, books and other media. This is precisely why, claimed Bartoszewski, the United States is "a great country." 102 Of course, it is very much debatable in what sense - and for what reason - the United States ought to be considered a "great country." Moreover, one could question how seriously Vietnam has really been dealt with in American popular culture. Indeed, many of the films and books produced in the United States on Vietnam, Bartoszewski’s hypothetical interlocutor could argue, might actually serve other purposes.

Regardless of where one stands on those kinds of issues, Bartoszewski's point is interesting precisely because he identifies a reflective approach to history and a capacity for self-

101 “Address Delivered by Władysław Bartoszewski, Polish Minister of Foreign Affairs, Holocaust Memorial Museum in Washington, DC, 5 April 2001" in The Neighbors Respond, 129.

102 Ibid. 
criticism as being essential traits for Poland moving forward. During the communist era, of course, this was not possible. ${ }^{103}$ The version of history put forward by the state simply could not be openly challenged without facing potentially serious consequences. At the same time, the myths of resistance and heroism that obscured the troublesome story of Polish-Jewish relations went unchallenged. Thus, in many ways, Gross's book—and the ensuing debate it spawnedwas representative of an important part of the transition from a communist to a post-communist society. Furthermore, it is interesting to note, with the release of films like Pokłosie and Ida, that perhaps Bartoszewski's hope is coming true. It remains to be seen, however, how many additional films and other artistic projects will be made, and the question of whether or not they will be successful in addressing the Polish-Jewish past in a serious, meaningful way is still very much an open question.

The former Prime Minister of Poland, Jerzy Buzek, also addressed the slaughter of Jedwabne's Jews in the aftermath of Neighbors. Buzek noted that "the participation of Poles in the crime in Jedwabne is indisputable; it isn't questioned by any respectable historian."104 This is, of course, true. While many scholars attacked Gross and Neighbors, it was not possible to seriously deny Polish participation in the pogrom, a conclusion which would be even further bolstered by the Institute of National Memory's study on the Jedwabne massacre. ${ }^{105}$ Buzek went on to claim the following: "We are ready to confront even the darkest facts of our history, but in the spirit of truth—without seeking presumed justifications." ${ }^{106}$ With that said, however,

103 The communist state frequently engaged in historical criticism, of course, but it was always done in an ideologically convenient way (e.g. criticism of capitalist exploitation throughout history).

104 "Living in Truth: Special Statement by Prime Minister Jerzy Buzek regarding the Slaughter of Jews in Jedwabne in 1941, April 2001" in The Neighbors Respond, 125.

105 "Findings of Investigations S 1/00/Zn into the Murder of Polish Citizens of Jewish Origin in the Town of Jedwabne on 10 July 1941, pursuant to Article 1 Point 1 of the Decree of 31 August 1944" in The Neighbors Respond, 125.

106“Living in Truth" in The Neighbors Respond, 125. 
Buzek expressed more reservation than either Bartoszewski or Kwaśniewski. He pointed out, for instance, that Poland was an occupied country during the pogrom and that the slaughter was "not committed in the name of the nation, or in the name of the Polish state."107 While that was undeniably true, Buzek's defensive posture failed to deal with the historical presence of antiSemitism in Poland. This captures some of the underlying tension in the Polish response to Gross's revelations about Jedwabne.

It would be absurd to suggest that there is some kind of unified Polish memory of Jedwabne. As Benedict Anderson famously theorized, nations are simply imagined communities, and it is far from obvious that there is much more holding nations together than imagination. There is, of course, no single unified Polish psychology, and thus there is not a sole authoritative Polish interpretation of any historical event. Naturally, indeed, if there were not many Poles who disagreed with many of the sentiments outlined above there could not have been such a large, polemical debate. To take one example, consider the view expressed by Lech Wałęsa: "The Jedwabne crime was a revenge for the cooperation of the Jewish community with the Soviet occupant. The Poles have already apologized many times to the Jews; we are waiting for the apology from the other side because many Jews were scoundrels." 108 Of course, this inflammatory statement demonstrates that there certainly was no consensus among prominent Polish political figures on how to respond to the Jedwabne massacre, and it additionally serves as a good example of the sometimes fierce response by those who wanted to cling to the older myths of Polish history.

107 Ibid.

108 “Kielce: More Shame in Poland's History,” Jerusalem Post, July 1, 2001. 
It is also revealing that the monument dedicated to the Jewish victims of Jedwabne has been the subject of vandalism. For example, in 2011 graffiti was added to the monument with phrases like "I do not apologize for Jedwabne" and "They were flammable."109 Once again, this powerfully illustrates the extremely divisive nature of the memory of the Jedwabne massacreespecially toward the stances taken publicly by the Polish government. Unsurprisingly, given his apparent commitment to confront this troubled past, Komorowski condemned this act of vandalism. ${ }^{110}$ All of this, to reiterate, serves as a good case study in documenting the often heated nature of the dispute and the importance of its discussion for Polish memory. Furthermore, it helps to show that Poles have had diverse responses to the Neighbors controversy, and it would be a gross oversimplification to try to present a single, coherent response to the debate over the Jedwabne pogrom. With that said, however, it is certainly worth pointing out that these vandals were likely supported by a relatively small percentage of the Polish population, and it would be wise not to exaggerate the meaning of this incident. Still, it is undoubtedly a disturbing episode, and it is powerful evidence that anti-Semitism is still very much alive in Poland today_even if it reveals little about how prevalent anti-Semitism is throughout Polish society.

Nonetheless, there are certain facts that the official political response to the Neighbors controversy sheds light on. For example, it is apparent that in the wake of Gross's challenge to Polish national memory the government largely adopted a tone of apology toward Jews. This was by no means accepted by everyone within the Polish state, yet it is clear that the Polish

${ }^{109}$ Tomasz Nieśpiał, “ABW do Jedwabnego,” Rzeczpospolita, http://www.rp.pl/artykul/17,710609-ABWszuka-wandali--ktorzy-zniszczyli-pomnik-w-Jedwabnem.html.

${ }^{110}$ Katya Andrusz, "Polish President Condemns Vandalism of Jewish Massacre Memorial," Bloomberg, http://www.bloomberg.com/news/2011-09-02/polish-president-condemns-vandalism-of-jewish-massacrememorial.html 
government made a meaningful effort to confront the demons of history in a serious, deliberate manner. Because the Polish state is both a literal and symbolic representative of the Polish people, this response marked a significant moment in Poland's attempt to engage with its history, i.e., in the process of Vergangenheitsbewältigung. ${ }^{111}$ The government's response also represents an important part of the process of reframing Polish-Jewish relations. Given the virtual absence of the Jewish community in contemporary Poland, moreover, these issues needed a book like Neighbors to be brought to the public's attention.

\section{Artistic Commemoration}

The complex and confused response to the Jedwabne pogrom is also evident in some of the artistic commemoration that has appeared in the aftermath of the Neighbors controversy. Consider, for example, the aforementioned film Poktosie, which was released in 2012 and is among the best examples of this phenomenon. This film, much like Gross's book, proved to be extremely controversial. Written and directed by Władysław Pasikowski, Poktosie tells the story of two brothers. The film begins when the elder brother, Franciszek Kalina, who is played by Ireneusz Czop, returns to his hometown in Poland after a prolonged absence, which he spent as an immigrant in Chicago. Upon his return, Franciszek is shocked to discover that his brother, Józek Kalina, who is played by Maciej Stuhr, has become something of a pariah in the town. This is due to Józek's attempt to reconstruct a Jewish cemetery. Indeed, after discovering that the tombstones of the town's Jewish inhabitants had been scattered during the Second World War, Józef begins to collect the tombstones—-sometimes at great personal expense—and rebuild

\footnotetext{
${ }^{111}$ Nevertheless, it must also be stressed that the Polish state was very reluctant to wholeheartedly acknowledge Polish responsibility for Jedwabne. Even Kwaśniewski repudiated the notion of collected guilt in his speech and apologized only "in the names of those Poles whose conscience is moved by (the Jedwabne pogrom);" Address by President of Poland Aleksander Kwaśniewski” in The Neighbors Respond, 131-32.
} 
the town's Jewish cemetery. The townspeople, however, are infuriated by these actions. Józek is badly beaten up by several men at one point, and Franciszek is constantly threatened throughout the film as well. It is then revealed that many of the townspeople directly benefited from the extermination of the town's Jewish population. In fact, the two brothers are shocked to discover that their own farm had been illegitimately acquired from a Jewish family that had been eliminated during the Holocaust, but even this is not the full story.

The film's final twist becomes clear when the two brothers discover that the town's Jewish inhabitants were not killed by Nazis. On the contrary, the town's Jews were collectively forced into the Kalina family's barn and burned alive by their neighbors. Even more devastating for the brothers, it is revealed that their own father participated in this massacre and even helped set fire to the building. This revelation proves too much for Józek, who become convinced that covering up the atrocity is necessary. Their only option, Józek reasons, is to secretly rebury the bones in the mass grave that the two brothers had found on their family's original property. The shame is too great, and if brought to the public's attention it will lead to an embarrassment for his family, the town and even the entire Polish nation. Franciszek, however, argues that that the two brothers need to expose the crime and rebury the bones in their new cemetery. Franciszek finally wins the argument when he boldly claims, “This world is a lousy shithole. And we won't make it one bit better, but you know what? We won't make it worse. And that's something."112 Here it is evident that Franciszek understands that, echoing some of the sentiments from Kwaśniewski's speech, the crime cannot be undone, but it is not too late for the brothers to do what is necessary - even if it embarrasses themselves, their community and the entire nation. Following Józek's brutal death at the hands of townspeople, the bones are reburied, and the film 
ends with Franciszek paying his respects to the town's murdered Jews while a rabbi, who is accompanied by many Jewish mourners, performs a funeral ceremony for the town's murdered Jews. The truth has at last come out.

In many ways this film symbolizes a number of the key issues brought to the forefront by Gross's book. It is undoubtedly important that Józek has to die. Indeed, in the end Józek wants to cover up the past, to obscure this dark and embarrassing chapter of his family's history. The bones, which he wants to stay hidden, serve as a larger metaphor. To conceal them is to both literally and figuratively conceal the past, which is necessitated in his mind by the disturbing secrets that he and his brother had uncovered. It is only once this mentality dies, moreover, that the truth can surface, making reconciliation possible. While the film does not proclaim that Polish-Jewish reconciliation has been achieved, the possibility is strongly suggested. The Jews are able to mourn their deceased properly once the bones are buried in the Kalina cemetery and Franciszek watches them from afar, perhaps making peace with his own connection to the massacre. It is significant, however, that he appears to be the only non-Jew at the ceremony. The rest of the town, it appears, is still reluctant to embrace the town's true history. This is reminiscent of the actual town of Jedwabne. For instance, one ought to note that the majority of Jedwabne's population opted to boycott the sixtieth anniversary ceremony of the slaughter. ${ }^{113}$ While many Poles have been able to accept what transpired at Jedwabne in 1941, acknowledging this tragic truth has been especially difficult for the inhabitants of Jedwabne, who- - like Franciszek and Józek — have a very close connection to the pogrom. 
During the communist era, of course, when officially promoted myths of the Second World War were much harder to criticize, films which dealt with Polish-Jewish relations were a rarity. ${ }^{114}$ Furthermore, in those few films which did address these issues, in the words of Marek Haltof, "History is presented either as a nightmare everybody would like to forget or as an almost nostalgic picture stressing the multinational character of prewar Poland."115 Pokłosie, of course, does not fit into either model, offering neither a nostalgic nor romanticized view of the past. On the contrary, Pokłosie exposes a dark chapter in Polish history, revealing the murderous extent of Polish anti-Semitism. Even the film's main hero, Franciszek, displays anti-Semitic tendencies when, on several occasions, he expresses his dislike for Chicago's Jewish population. Moreover, the rest of the town's extensive anti-Semitism is on display throughout the film, as the townspeople routinely do everything in their power to prevent the two brothers from discovering the truth-often through violent means. Returning to the first model outlined by Haltof, it is also evident that this is no nightmare to forget. Instead, the film suggests, this is a nightmare that must be remembered. Pokłosie thus depicts Polish-Jewish relations in a novel way and is clearly inspired by Neighbors. Just as the two brothers must come to terms with the past, the film implies, so too must Poland come to terms with Jedwabne.

Ultimately, Pokłosie is a continuation of the Neighbors controversy, and it is a film that is very transparently framed by Gross's book. It also attracted tremendous controversy, which helps to further reveal something about the highly contested nature of Polish collective memory on these issues. In an interview the historian Bogdan Musiał, who of course is one of the best known critics of Neighbors, argued that Pokłosie perpetuated falsehoods found in Gross's work

\footnotetext{
${ }^{114}$ Marek Haltof, "National Memory, the Holocaust, and Images of the Jew in Postwar Polish Films" in Polish National Cinema (New York: Berghahn Books, 2002), 222.

115 Ibid, 239.
} 
and that the film presented Poles as a "dangerous mob."116 Musiał, in that same interview, even went so far as to suggest that the progressive thinking behind the film had its roots in Stalinism. Furthermore, another previously mentioned critic of Neighbors, Marek Jan Chodakiewicz, also attacked the film extensively in an interview. ${ }^{117}$ Indeed, Chodakiewicz alleged that Pokłosie is an attempt to manipulate the Holocaust and make Poles feel ashamed of their heritage. Similar to Musiał's analysis, Chodakiewicz's criticism clearly has political undertones, and there is an obvious fear that the representations of history offered by both Neighbors and Poktosie are a threat to Polish national memory.

Another fascinating and revealing example of artistic commemoration is evident in Rafał Betlejewski's act of symbolically burning a barn. This incident is documented in a short film Betlejewski produced titled Płonie Stodoła. ${ }^{118}$ Essentially, Betlejewski erected a barn in the village of Zawada, and then he subsequently incinerated this barn. Moreover, small sheets of paper, which symbolized Poles taking the place of the murdered Jews of Jedwabne, were left scattered across the floor as Betlejewski set fire to the barn. Like the reception of Neighbors, which Betlejewski admitted had inspired this action, the responses to this act were both conflicted and confusing. A surprisingly large number of spectators turned up at the event, and two young males, arguing that Betlejewski's act "trivializes and devalues the symbols of the Holocaust," 119 decided to protest the event by refusing to leave the barn. The two protestors only left after being physically threatened by spectators who wanted to watch the barn burn. One commentator, Maria Antonia Szpunar, argued that Betlejewski was "turning Jedwabne into a

\footnotetext{
116 Rafał Kotomski, "Nasz Wywiad: „Pokłosie” Powiela Fałsz Historyczny,” Niezalezna, http://niezalezna.pl/34816-nasz-wywiad-poklosie-powiela-falsz-historyczny

${ }^{117}$ Rafał Kotomski, "Nasz wywiad: Chodakiewicz o "Pokłosiu, " Niezalezna, http://niezalezna.pl/34816nasz-wywiad-poklosie-powiela-falsz-historyczny

118 Rafael Betlejewski, "Płonie Stodoła," http://www.youtube.com/watch?v=r21Jur404Lo

119 Ibid.
} 
circus." 120 Zuzanna Marczynska expressed an entirely different concern: "Rafał, don't burn this barn. You mustn't! Think about the citizens of Jedwabne. This barn will painfully mark them again with the guilt of this crime." ${ }^{121}$ One final commentator, wishing to remain anonymous, argued that Betlejewski had no right to speak for the Polish people. In many ways, Betlejewski's action functions as a microcosm of the larger debate over the memory of Jedwabne. Indeed, the responses were extremely diverse and —in some cases - very angry. The purpose of Betlejewski's action, to symbolically burn up the person he was prior to his understanding of Jedwabne and its importance for Polish-Jewish relations, aligns very nicely with Gross's determination to overturn the myths of Poland's past. Furthermore, this incident demonstrates a strong desire to take responsibility for the past, which is practically demanded by Gross's work.

Another attempt to commemorate Jedwabne artistically can be seen in Eva Hoffman's play The Ceremony. Hoffman hoped that her play would "act as a kind of ceremony, an enactment of communal conflict, mourning, and atonement and ultimately of a difficult, chastening exorcism." 122 Her play, moreover, adequately captures a number of the diverse responses to Gross's revelations about the horrors that transpired at Jedwabne in 1941. For instance, in one scene there are two men who converse with a blacksmith. Over the course of their conversation it becomes apparent that they actually miss the Jews-even though it is implied that they took part in the massacre. ${ }^{123}$ This same theme, a yearning for the Jews to return to Poland, is also eloquently on display in Yael Bartana's film, Koszmary or Nightmares,

\footnotetext{
120 Ibid.

${ }^{121}$ Ibid.

${ }^{122}$ Eva Hoffman, "The Ceremony (Excerpts from a Play)," in Imaginary Neighbors: Mediating PolishJewish Relations after the Holocaust, ed. by Dorota Glowacka and Joanna Zylinska (Lincoln: University of Nebraska Press, 2007), 149.

123 Ibid, 150-153.
} 
the first of Bartana's so-called Polish trilogy, in which Sławomir Sierakowski offers an impassioned plea for three million Jews to return to Poland and once again live alongside their Polish neighbors. ${ }^{124}$ It is significant to note that this scene was staged in the old Warsaw soccer stadium, which was built in part from the ruins of the Warsaw Ghetto. This stadium would later be demolished to make way for the construction of Warsaw's new stadium prior to the 2012 European Cup.

Returning to Hoffman, however, there is another scene in The Ceremony in which a host of individuals - some inhabitants of Jedwabne, others who have come from afar-listen to the President's apology speech. The reaction is mixed. One spectator, for example, Piotr, regards the speech as "redeeming our Polish soul." 125 Rachel, a Jew from Baltimore whose grandparents were from Jedwabne, rejects this explanation: "What a concept! You think an apology is... enough?! After everything that has happened here?"126 The meaning of the president's apology — and especially its moral significance — is highly contested in the play. This is, of course, consistent with the response to Kwaśniewski’s actual apology speech. Still, arguably the most important thing here is the recognition that something horrible happened and the struggle over how to interpret this uncomfortable truth. Though the proper response to the memory of this event being unearthed is unclear, much of the debate and ambiguity rests with the issue of responsibility. Piotr, indeed, annoyed by Rachel's accusations, claims, "You, you, who do you think you're speaking to? Do you think I did those things?"127 The nature of moral responsibility—especially as it relates to collective responsibility—is a vexing philosophical

${ }^{124}$ Yael Bartana, "Nightmares," Filmoteka Muzeum, http://www.artmuseum.pl/filmoteka/?l=1\&id=200, April 29, 2013.

${ }^{125}$ Hoffman, "The Ceremony," in Imaginary Neighbors, 176.

${ }^{126}$ Ibid, 177.

${ }^{127}$ Ibid, 179. 
issue that Hoffman does not attempt to resolve in her play. With that said, it is particularly illuminating that The Ceremony attempts to address such questions. Hoffman's play ultimately takes on the difficult task of engaging history—just like Pokłosie, Koszmary or Płonie Stodołaand is thus an important example of the recent post-Neighbors attempt to address the complex issue of Polish-Jewish relations through artistic media.

Of course, this discussion cannot be complete without analyzing the most recent effort to address the Polish-Jewish past through film, namely, Paweł Pawlikowski 2013 award-winning drama Ida. Much like Pokłosie, Pawlikowski's film focuses on the issue of a disturbing history coming to light. The film's protagonist, Ida, played by Agata Trzebuchowska, is a Catholic novice on the verge of becoming a nun. Before fully joining the convent, Ida is introduced to her only living relative: her aunt Wanda Gruz, a communist judge who earned the nickname "Red Wanda" in the 1950 s due to her apparent zeal and ruthlessness. Wanda, played by Agata Kulesza, reveals to Ida her secret Jewish lineage. The revelation that Ida is actually a Jewish nun proves quite shocking for the young novice, which prompts both her and Wanda to search for answers about what became of her parents during the war. Their inquiries into the fate of Ida's family prove difficult, but eventually Wanda and Ida discover the truth: Ida's parents were ruthlessly murdered and their bones were buried in the forest. Ida's parents, the Lebensteins, were apparently killed by the Skiba family who hid the Lebensteins during the early stages of the Nazi occupation. They then stole Ida's parents' home, which is now occupied by the family of Feliks Skiba. In exchange for renouncing her claim to her parents' home, Feliks promises to take Ida and Wanda into the forest where the bones are buried, an offer which Ida has no choice but to accept. There they discover what's left of Ida's parents and Wanda's young son, who was also in hiding with Ida's family. The grim discovery proves too much for Wanda, who eventually 
kills herself toward the end of the film. Ida wonders why she also was not buried in the shallow grave, and Felix reveals that unlike Wanda's son—who had a dark complexion and had been circumcised — she could pass for a Pole, so she escaped the rest of her family's fate and was abandoned at an orphanage.

The unearthing of the bones of Ida's family is a powerful metaphor for the unearthing of the history of Polish crimes during the Holocaust. Just as the Kalina brothers are forced to wrestle with the question of how to respond to the dark secrets they uncover, so too must both Ida and Wanda. After the two women rebury the bones at a Jewish cemetery, Ida's entire identity is left completely shattered. She is seen consuming alcohol and even sleeps with a man, a clear violation of her vows. With her identity in tatters, Ida now seems out of place at the convent. While she does not choose death like her aunt, the purpose of Ida's life is profoundly shaken and her future as a nun is left unclear by Pawlikowski. Additionally, it is worth noting that the central crime of the film—namely, the murder of Ida's family by Feliks Skiba-is left ambiguous and only partially explained. Perhaps Feliks murdered the Jews he was hiding out of a misplaced desire to protect his family, but it seems more likely that he had anti-Semitic motivations. Perhaps he bought into the myth of the greedy Jew and simply wanted to steal the family's property. ${ }^{128}$

Ultimately, Ida is a very good film, a conclusion shared by many critics around the world, which is further bolstered by the numerous awards it has won-including the 2015 Academy Award for Best Foreign Language Film and the 2014 European Film Award for Best Film. The film's cinematography is undoubtedly excellent. Ida's quest to discover the fate of

\footnotetext{
128 Jeremy Hicks, "A unique exploration of Poland's unspoken, unspeakable history - Ida is spectacular," last modified September 30, 2014, http://theconversation.com/a-unique-exploration-of-polands-unspokenunspeakable-history-ida-is-spectacular-32301
} 
her family is set against a haunting black-and-white backdrop. What is particularly haunting, however, is not just what is shown; it is also what Pawlikowski chooses not to show-e.g. the bones of Ida's family. Instead, the viewer often experiences the horrors of the film by witnessing the emotions and expressions of the film's main characters directly. Perhaps equally haunting, however, is the film's reliance on silent reflection. As Jeremy Hicks has been pointed out, Pawlikowski has a deep sensitivity to the unsayable ${ }^{129}$, which is constantly on display in Ida, a film that does not need to rely upon dialogue to convey emotion and meaning. Moreover, this reliance upon silence resonates nicely with the often unspeakably traumatic nature of the memory of the Holocaust in Poland.

The reception of Ida in Poland was probably better than that of Pokłosie. Indeed, many Poles responded to Pawlikowski's film quite favorably, and Ida won numerous awards in Poland—including the Polish Film Academy's awards for Best Film, Best Actress, Best Director and Best Editing. ${ }^{130}$ Nevertheless, as is almost always the case when the history of Polish Jews is brought up in Poland, the film also inspired controversy. Recently the Polish anti-Defamation League, for example, launched a campaign to condemn Pawlikowski's film, which resulted in numerous signatures by Polish right-wing nationalists. ${ }^{131}$ This petition, which demands that Ida include a number of disclaimers acknowledging the Nazi occupation and culpability for the Holocaust and Poland's many heroic efforts to save Jewish lives, has now been signed by more than 50,000 individuals. ${ }^{132}$ Tadeusz Płużański, moreover, maintains that $I d a$, despite its artistic

\footnotetext{
129 Ibid.

130 “Laureaci wg roku - 2014,” http://pnf.pl/laureaci-wg-roku-2014/.

${ }^{131}$ Andrew Pulver, "Polish nationalists launch petition against Oscar-nominated film Ida," last modified January 22, 2015, http://www.theguardian.com/film/2015/jan/22/ida-oscars-2015-film-polish-nationalists-petition

${ }^{132}$ Maciej Świrski, “Umieszczenie informacji o kontekście historycznym, w jakim odbywa się akcja „Idy” jest konieczne," last modified February 23, 2015, http://wpolityce.pl/kultura/234837-umieszczenie-informacji-okontekscie-historycznym-w-jakim-odbywa-sie-akcja-idy-jest-konieczne
} 
value, continues the alleged misrepresentations and "anti-Polish tone" found in Gross's work and Pokłosie. ${ }^{133}$ Pawlikowski's film, finally, has even been described as "anti-Polish propaganda disguised as art."134 Ultimately, the film's presentation of history remains highly contested, and it is evident that Ida has once again posed a significant challenge to the national memory of the Polish-Jewish past.

Now it is necessary to return to the question that naturally arises out of Bartoszewski's 2001 speech, i.e., how successful have these attempts at artistic commemoration been at addressing these issues in a serious, meaningful way? Purely on an intellectual level, these works have clearly succeeded in engaging with Gross's revelations about the Jedwabne massacre in a nuanced way. In the end, it is apparent that these works of art are an important part of Poland's attempt to deal with its past. Just as many Polish politicians stepped up and addressed the controversy, so too have Polish artists and filmmakers. While the average Pole may not necessarily be familiar with all of these works, it is nevertheless symbolically important that these issues have been addressed through various artistic media. Furthermore, these artistic developments are representative of larger shifts occurring within Poland—shifts which are part of a broader, cumulative process that is altering Polish conceptions of history and helping to reshape Polish-Jewish relations.

133 Tadeusz Płużański, “Nowe Pokłosie,” last modified January 7, 2015, http://niezalezna.pl/63018-nowepoklosie

${ }^{134}$ Krzysztof Łuksza, "Ida to antypolska propaganda - recenzja” last modified February 24, 2015 , http://wokolzycia.blox.pl/2015/02/Ida-recenzja.html 


\section{Chapter Four: Other Works by Gross}

Neighbors ultimately presented a profound challenge to Polish collective memory. By undermining Polish myths of heroism and victimization during the Second World War, Gross's book brought to the forefront a novel way of assessing Poland's wartime history, which had important implications for Polish-Jewish relations. Of course, while they were certainly a small minority, many Poles really did act heroically during the war, and that history has been welldocumented. ${ }^{135}$ Additionally, Poles suffered traumatic devastation-in material, physical and psychological terms - during the Second World War. Neither of these histories can or should be denied. With that said, Gross helped to show that there was more to Polish wartime history than these experiences. Within Poland, indeed, there is an undeniable history of anti-Semitism, and it is crucial to assess this history and to try to understand the memory politics that sought to marginalize or distort it.

Gross's book was not the first to address the vexing topic of Polish-Jewish relations in a provocative way, and it is important not to overstate the role of Gross and Neighbors in the Memory Wars and the reframing of Polish-Jewish relations. Instead, this is the result of a large and collaborative process, which began as the communist era was coming to a close and is still very much ongoing. Perhaps the best book on the subject that predated Gross is Michael Steinlauf's Bondage to the Dead: Poland and the Memory of the Holocaust. Steinlauf, who like Gross is of Polish-Jewish ancestry, documents the experience of Polish Jews during the Second

${ }^{135}$ See, for example, Nechama Tec, When Light Pierced the Darkness (New York: Oxford University Press, 1986). For additional documentation, see Bill Tammeus and Rabbi Jacques Cukierkorn, They Were Just People: Stories of Rescue in Poland during the Holocaust (Columbia: University of Missouri Press, 2009) or Irene Tomaszewski and Tecia Werbowski, Code Name Żegota: Rescuing Jews in Occupied Poland, 1942-1945 (Santa Barbara: Praeger, 2010). 
World War, and he also rigorously analyzes the construction of Holocaust memory in Poland. ${ }^{136}$ But ultimately, it was Neighbors that really brought the discussion to a level of public scrutiny that had never been possible before. In part, this was because Neighbors was originally published in Polish and aimed at a Polish audience, while Steinlauf's book was aimed at an Englishspeaking audience. For this reason the publication of Neighbors is a crucial moment in the Memory Wars — and quite possibly the most important moment — and this explains why Gross requires so much attention in this analysis.

Still, to understand the challenges posed by Gross's research it is necessary to go beyond Neighbors. Indeed, Gross did not simply leave the discussion to Polish scholars and journalists after his groundbreaking work on the Jedwabne pogrom. Since the publication of Neighbors, Gross has written two additional books - namely, Fear and Golden Harvest - that continue his assault on Polish national mythology. In order to understand Gross's place in the Memory Wars, it is necessary to incorporate these works into the discussion and evaluate how they contributed to the debates on Polish-Jewish relations; similarly, one must also assess the responses elicited by these works.

\section{Fear Controversy}

Fear was published in 2007. Unlike Gross's earlier work Neighbors, it was first released in the United States; thus, even before the Polish version's publication, the book was under attack - particularly by the Polish-Catholic press — and characterized as "deceitful" and "antiPolish." 137 Furthermore, Fear did not provide a revolutionary account of a topic within Polish

\footnotetext{
${ }^{136}$ Michael C. Steinlauf, Bondage to the Dead: Poland and the Memory of the Holocaust (Syracuse University Press, 1997).

${ }^{137}$ Forecki, 215.
} 
historiography. ${ }^{138}$ There was no need, indeed, for the kind of radical revisionist history that Jedwabne required. On the contrary, the arguments and conclusions in Fear did not rest upon any new historical evidence, and thus it was much harder for critics to attack Gross's handling of the facts. ${ }^{139}$ Much like Neighbors, however, the response to Fear was quite diverse and very polemical. Gross's supporters viewed this work as a welcome addition to the growing literature that reassessed the history of Polish Jews. Many of Gross's critics, however, continued to react harshly and with much vitriol.

In Fear, Gross reveals the story of Poland's surviving Jews in the aftermath of the Second World War and the Holocaust. Even after liberation from Nazi rule, Polish Jews suffered tremendously. Taking a special place in Gross's book is the Kielce pogrom, which was the deadliest peacetime pogrom in twentieth-century Europe. Essentially, Gross attempts to engage with the question of how this sort of massacre was possible following the Third Reich's defeat. Why, Gross asks, might even those responsible for saving Jewish lives during WWIIthe so-called Righteous Among the Nations - fear that their heroic actions would become known throughout their communities? And what sort of factors, ultimately, contributed to this deeply anti-Semitic atmosphere in postwar Poland?

One of Gross's most interesting points concerns the opportunistic nature of many of the Polish wartime crimes committed against Jews. Gross points out, for example, that a vast amount of Jewish wealth was plundered by both Poles and Nazis. Moreover, this experience was common throughout the Holocaust and its aftermath, an issue Gross explores in much greater depth in Golden Harvest. Jews, rather disturbingly, became something like a commodity or

\footnotetext{
${ }^{138}$ For an earlier discussion of the Kielce pogrom, see Bożena Szaynok, Pogrom Żydów w Kielcach, 4 lipca $1946 r$. (Warsaw: Bellona, 1992).

${ }^{139}$ Forecki, 216.
} 
resource needed to be harvested during this time. Nothing was off limits in this avaricious quest for wealth. Jewish graves, indeed, were routinely plundered in the hopes of finding something of value that others might have missed. Furthermore, there was also a sense that Poles were entitled to Jewish possessions and property. In the minds of the perpetrators of these heinous deeds, the wealth accumulated by Jews was fair game and this harvest needed to be fiercely guarded from outsiders. Gross recounts one story in which Poles from Wąsosz arrived in Radziłów to take part in the slaughter of Jews. Because they were seen as being from too far away, these men were chased away, but Poles arriving from Konopki, a much closer town, were allowed to take part in the slaughter and subsequent harvest. "Evidently," Gross declares, "a town's Jews were for the town's people to plunder."140

Gross documents post-war pogroms in Kraków and Kielce — with a particular emphasis on the latter. The perpetrators of these atrocities were motivated, at least on the surface, by the anti-Semitic belief that children were being kidnapped and ritually murdered by Jews. Another notion that helped to fuel this violence was the belief that Jews were in some sense deeply connected with communism, the myth of żydokomuna. It was this belief, Gross notes, that prompted Catholic hierarchs to claim that "the Jews were Communists and that they brought all their misfortunes upon themselves." ${ }^{141}$ But why and how did such an atrocity occur? Gross argues that there was nothing particularly unique about Kielce. Indeed, the pogrom could have occurred anywhere throughout Poland. Gross additionally criticizes the provocation hypothesis, or prowokacja, of the Kielce pogrom. This is the thesis that the communists, perhaps with the aid of Jews hoping to engender a Jewish departure en masse to Israel, intentionally brought about

\footnotetext{
${ }^{140}$ Jan T. Gross, Fear: Anti-Semitism in Poland after Auschwitz (New York: Random House, 2006$), 42$.

${ }^{141}$ Ibid, 152.
} 
the Kielce slaughter. For Gross, however, there is "no material evidence to support such a scenario."142 Returning to the issue of żydokomuna, Gross naturally sets out to disabuse his readers of this notion. While Gross concedes that Jews were disproportionately involved in communist or socialist movements, he makes it clear that this is because Jews had no other viable political options. They were simply not welcome anywhere else. Ultimately, Gross declares, Jews did not force communism on Polish society. On the contrary, Gross argues for precisely the opposite conclusion, i.e., communism was forced on Poland's Jews by the antiSemitism that characterized Polish society. Moreover, the communist government that emerged in the aftermath of the Second World War chose to adopt an approach that Gross describes as "not very benign neglect with respect to the 'Jewish problem.",143

Ultimately, Gross does not offer a simple diagnosis for the outburst of anti-Semitic violence in the aftermath of WWII in Fear. The reasons are nuanced and multicausal. Greed has already been noted; anti-Semitism, indeed, had the potential to be quite profitable for those willing to partake in the golden harvest, but there was much more to it than that. Because the Jews had been victimized by their Polish neighbors during the Holocaust, Gross asserts, their survival represented something disturbing in the minds of Poles — something that was not tolerable. It was thus what the Poles had done to the Jews, and not what the Jews had done to the Poles, which motivated these crimes. This realization prompts Gross to quote Tacitus, who noted that all people "have a propensity to hate those whom they injured."144 According to Gross, it was inevitably easier for Poles to eliminate these surviving Jews - who may have come

\footnotetext{
142 Ibid, 161.

143 Ibid, 242.

144 Ibid, 256.
} 
back for their property or sought redress in other ways for the crimes committed against themthan to seek harmony, forgiveness or reconciliation.

Given these profound challenges to Polish memory, it is not surprising that Fear would be attacked by many Polish scholars. For example, Marek Jan Chodakiewicz, who authored a book in response to Fear called After the Holocaust, argued in an interview with Rzeczpospolita that Fear perpetuated misinformation found in Gross's earlier work. More specifically, he accused Gross of approaching the debate with a preconceived notion of "universal, bloodthirsty Polish anti-Semitism" that distorts his historical writing. ${ }^{145}$ In addition to arguing that the outburst of violence documented in Fear was confined to only a handful of isolated incidents, Chodakiewicz attacked Gross for drawing larger conclusions about the extent of anti-Semitism across Poland. Instead, Chodakiewicz maintained, one ought to only speak about individual cases. Furthermore, Chodakiewicz lambasted Gross for his alleged postmodernism and accused him of being little more than a propagandist. Just as in Musiał's criticism of Pokłosie, Chodakiewicz linked Gross's presentation of Polish crimes against Jews with Stalinism. ${ }^{146}$ In After the Holocaust, moreover, Chodakiewicz does not really reply to Fear directly; instead, he attempts to reestablish the narrative of victimization in order to minimize the severity of Gross's arguments. ${ }^{147}$ For Chodakiewicz and many other scholars, ultimately, it is paramount to defend a nationalistic presentation of Polish history that excludes all inconvenient facts. Any historical injustices can only be considered as isolated, individual incidents, and there can be no larger

145 Piotr Zychowicz, “Chodakiewicz: Ludzi należy rozliczać indywidualnie,” Rzeczpospolita, http://www.rp.pl/artykul/82902.html?p=1

146 Ibid.

${ }^{147}$ Forecki, 228. 
social, political or cultural context within which to discuss these crimes. Chodakiewicz's presentation of history absolves Poland a priori from the need to confront the past.

The harsh reaction to Fear was not limited to scholars, however. Gross's book was considered so insulting and problematic that right-wing legislators actually proposed taking serious legal action, which could have resulted in Gross's arrest. Indeed, Jerzy Engeling, the Public Prosecutor General Deputy, assured these legislators that he would examine the case, but fortunately no charges were ultimately pursued. ${ }^{148}$ In response to the threat of legal action taken to silence him, Gross promised to show up in court and fight the charges if any were brought against him. Additionally, Gross pledged to bring witnesses to the stand that would confirm his account of events. ${ }^{149}$ As Piotr Forecki has pointed out, the fact that the Prosecutor's Office even addressed the case helped to discredit and invalidate Fear for many ordinary Poles.

Furthermore, other institutions — such as the Catholic Church and the Institute of National Remembrance - have also played a role in this invalidating process. ${ }^{150}$

\section{Golden Harvest Controversy}

The 2012 publication of Golden Harvest, which Gross wrote with his former wife, Irena Grudzińska-Gross, further complicated matters. As noted previously, in this text Gross documents the history of Poles profiting off of the Holocaust. He begins, indeed, with a disturbing photograph, which shows a group of Poles at Treblinka. Remarkably, these individuals, who are seen posing next to a pile of skulls and bones, were purportedly caught

${ }^{148}$ Ibid, 229-230.

${ }^{149}$ Adi Schwartz, "Historian threatens to reveal Polish atrocities against Jews if tried for slander," Haaretz, http://www.haaretz.com/news/historian-threatens-to-reveal-polish-atrocities-against-jews-if-tried-for-slander1.237256

${ }^{150}$ Forecki, 231. 
digging through piles of ashes in search of Jewish valuables just before the photo was taken. ${ }^{151}$ Not all of the individuals who participated in the golden harvest would dig through the ashes of the dead in the hopes of finding some treasure overlooked by the Nazis, of course. Gross argues instead that the process of enriching oneself at the expense of Jewish lives was quite diversified. For instance, it often happened as a result of ordinary transactions between individuals, in which Jews would give Poles their valuables for safekeeping. ${ }^{152}$ But all too frequently, Gross alleges, Poles would violate these agreements, keeping the valuables for themselves despite their commitments. ${ }^{153}$ During the war, Jews were hunted like animals by the Germans, and Polish peasants would sometimes join in these hunts. Furthermore, Poles have been documented participating in these hunts on their own initiative. ${ }^{154}$ Another way to participate in the golden harvest was simply by charging Jews for shelter during the Holocaust. ${ }^{155}$ This often involved extortion. If the Jews would or could not pay, they would be handed over to the Nazis. Given the widespread anti-Semitic stereotype of Jews hoarding away vast sums of money, it is not difficult to imagine how expensive survival might be, and there was still the threat of being turned in — even after making the agreed upon payment.

Ultimately, Gross's thesis in Golden Harvest calls into question many of the same issues discussed in both Neighbors and Fear. Once again, a troublesome history, in which Jews are victimized by their Polish neighbors, is brought into the public spotlight. And once again, a large number of critics denounced Gross's findings. Marek Jan Chodakiewicz emerged yet again as one of Gross's leading detractors. Indeed, for Chodakiewicz this work continued Gross's

${ }^{151}$ Jan Tomasz Gross and Irena Grudzińska Gross, Golden Harvest: Events at the Periphery of the Holocaust (Oxford University Press, 2012), 3.

152 Ibid, 80 .

153 Ibid.

154 Ibid, 82.

155 Ibid, 96. 
tendency to "demonize the Poles en masse," a feat which Gross managed to accomplish by ignoring "virtually all empirical and scholarly evidence that contradicts his theories." Chodakiewicz, moreover, attacked Gross for his use of the photograph - the authenticity of which cannot be verified - and his broader methodology. Gross is guilty of a myriad of logical fallacies and his style, says Chodakiewicz, is more like that of a literary critic rather than a serious historian. ${ }^{157}$ Gross even apparently failed to take into consideration basic human nature. ${ }^{158}$ Chodakiewicz, finally, attacked Gross for his emphasis on collective — rather than individual—responsibility. This is a perversion of the nature of moral responsibility, which is said to be "mea culpa" rather than "nostra culpa."159

In that same volume addressing Gross, which is provocatively titled Golden Harvest or Hearts of Gold?, Peter Stachura characterized Gross as an "anti-Polish propagandist.",160 Additionally, much like Chodakiewicz, Stachura attacked Gross for allegedly being wildly dishonest and accused his work of being incompatible with "traditional notions of sound, empirically supported, objective scholarship."161 As the title of Stachura's essay implies, i.e. “Insults Instead of Facts," Gross evidently relies upon attacking his opponents rather than using logic and argument. Piotr Gontarczyk offered a similar critique of Gross, who is portrayed as having no regard for the truth whatsoever. Indeed, Gross was pronounced guilty of "scholarly fraud."162 This is a common trend in many of the criticisms of Golden Harvest. Frequently,

${ }^{156}$ Marek Jan Chodakiewicz, "Reflections: A New Work but the Same Old Method," in Golden Harvest or Hearts of Gold?, ed. by Marek Jan Chodakiewicz, Wojciech Jerzy Musyński and Paweł Styrna (Washington, DC: Leopold Press, 2012), 21.

157 Ibid, 25.

${ }^{158}$ Ibid, 31 .

${ }^{159}$ Ibid, 62.

${ }^{160}$ Peter Stachura, "Insults Instead of Facts," in Golden Harvest or Hearts of Gold?, ed. By Marek Jan Chodakiewicz et al. (Washington, DC: Leopold Press, 2012), 65.

${ }^{161}$ Ibid, 64.

${ }_{162}$ Piotr Gontarczyk, "If the facts are against us, too bad for the facts," in Golden Harvest or Hearts of Gold?, ed. By Marek Jan Chodakiewicz et al. (Washington, DC: Leopold Press, 2012), 65. 
Gross is portrayed as an academic charlatan or a hack with no understanding of history. But then sometimes he is a presented as a cynical, malicious and intellectually dishonest propagandist on a crusade to discredit the Polish nation using any means possible. Many of these arguments blur the distinction between criticism and ad hominem.

In order to bolster the hearts of gold paradigm, Ryszard Tyndorf's essay documents the heroic rescue of Jews by Poles during the Nazi occupation of Poland. ${ }^{163}$ The same narrative is on display in Mark Paul's essay in the same volume, which documents the escape of Jews from Treblinka with the help of Poles. ${ }^{164}$ Of course, there is actually nothing fundamentally wrong with how these essays are written. What many of Golden Harvest's critics fail to recognize is that, in the very act of selecting a historical topic, one must exclude other topics. Choosing what to write about, indeed, necessarily entails choosing what not to write about. Gross, for example, is engaging with a particular history — one which for too long was not openly discussed. And that is why it is a significant challenge to Polish memory. When critics attack Gross for not adequately assessing acts of Polish heroism alongside Polish crimes, they are simply missing the point. In fact, in creating a false dichotomy between the golden harvest and the hearts of gold paradigms, the anti-Gross historians have done precisely what they oppose so much.

Furthermore, the literature on Polish victimization and heroism is extensively documented. Why do the critics of Gross not attack, say, the authors that describe these histories? One likely explanation is that they are too deeply committed to a nationalistic reading of Polish history, and they simply do not like what Gross argues.

${ }^{163}$ Ryszard Tyndorf, "Collective Rescue Efforts by Poles on Behalf of Jews," in Golden Harvest or Hearts of Gold?, 153-200.

${ }^{164}$ Mark Paul, "Rescue of Jewish Escapees from the Treblinka Death Camp," in Golden Harvest or Hearts of Gold?, 117-137. 
Many of Gross's critics are serious historians. Chodakiewicz, for example, is a decent scholar with respectable academic credentials. So are many of the other contributors to Golden Harvest or Hearts of Gold?, which is a highly polemical but occasionally interesting response to Gross's Golden Harvest. Many of the criticisms of both Fear and Golden Harvest are absolutely valid. When Gross's interlocutors allege that he writes history in a very unorthodox style, they are absolutely right. Gross frequently is prone to extrapolation and writes in a very literary style - sometimes without extensive documentation. To phrase the issue somewhat provocatively, Gross writes good history badly. Indeed, his history is good in the sense that it elevates important issues, which are not often well understood by the Polish public, into mainstream public discourse. Furthermore, these interpretations reflect troublesome realities that provide important challenges to Polish collective memory. Gross's history is written badly in the sense that it is not always framed in the manner expected by professional historians. Having a unique style is not necessarily a problem, however. Gross's style needs to be taken into account when reading his texts, and too often his interlocutors have discarded the principle of charity in the rush to tear down his ideas. When reading Gross and his critics, it is important to disentangle small picture criticism from big picture criticism. Small picture criticism, for example, includes issues like whether or not Gross adequately documents, say, the death toll at Jedwabne. This kind of criticism is absolutely worthwhile and necessary. Big picture criticism, however, is motivated by undermining — or perhaps completely discrediting - Gross's central project: namely, exposing the history of anti-Semitic violence in twentieth-century Poland. This kind of criticism is too often motivated by nationalistic sentiments and an unwillingness to confront unpleasant historical truths. 
So what, ultimately, can be said about the scholarly debates over Fear and Golden Harvest? In contrast to the discussions spawned by Neighbors, Piotr Forecki has argued that little meaningful progress has been made in the dialogues created by Gross's latter two books. ${ }^{165}$ On the one hand, Forecki's argument is plausible; after all, Gross and his interlocutors have become even more deeply entrenched in their views. The debates now seem stagnant, and many of Gross's most serious critics have become excessively venomous and polemical in their responses, and there are fewer voices in Poland coming to Gross's defense. These facts, coupled with the aforementioned threat of legal action, reinforce a truism: many Poles are now very tired of Gross and his assaults on Polish national mythology. On the other hand, however, Forecki is wrong about the impact of Gross's later works. Regardless of how these texts are perceived by the Polish press, the general public or academia, the arguments presented in Fear and Golden Harvest constitute important contributions to the literature on the history of Polish Jews. Gross's views have now been widely disseminated. While these views will likely continue to be very controversial for the foreseeable future in Poland, it is undoubtedly true that these texts have helped to address topics that were previously taboo. In that sense both Fear and Golden Harvest have helped to steer the discussion of Polish memory and hopefully will help to lay the foundations for future research, dialogue on Polish-Jewish relations and maybe one day even reconciliation.

${ }^{165}$ Forecki, 266. 


\section{Chapter Five: Current Status of Polish-Jewish Relations}

Poland's Memory Wars have likely not yet come to an end. There will almost certainly be additional challenges posed in various media-films, artwork, scholarly books, etc.- - that will continue to undermine excessively narrow and nationalistic accounts of Polish history. These challenges will almost certainly be met with opprobrium. The last twenty years of debate and dialogue have also shown that the responses will be extremely diverse and complex. With that said, today's Poland is dramatically different than Poland in the 1980s. With Poland's incorporation into NATO in 1999 and EU accession in 2004, Poland has undergone a radical strategic and political reorientation over the last few decades. Poland is no longer an authoritarian dictatorship with a state planned economy, but a flourishing democracy with an economy that is largely integrated with its new Western allies. While an economic gap with its Western and Northern European counterparts still remains, Poland is no longer a country in transition. The return to Europe is now largely complete.

Ultimately, no single social or political issue over the last couple decades has attracted as much controversy as the question of Polish anti-Semitism, which is one of the most important issues at the heart of the Memory Wars. How have Poles historically viewed Jews living in Poland? And how have those attitudes changed in recent years? In order to assess the impact of the Memory Wars, one must grapple directly with the question of anti-Semitism in Poland. This cannot be viewed solely as an historical problem. Indeed, one must try to assess the current prevalence of anti-Semitic attitudes in contemporary Poland and explore how they have changed over the last few decades. This will require an in-depth analysis of polling data. Additionally, whereas the existing literature on Polish-Jewish relations has been almost exclusively framed by cultural and political elites, this will help to shed light on the views of ordinary Poles. First, 
however, it will require a discussion of new ways that the history of Polish Jews is being presented to the public. Perhaps the most important example here is the POLIN Museum of the History of Polish Jews, which opened in 2014.

\section{POLIN Museum of the History of Polish Jews}

The construction of memory is a dynamic social process that is highly politicized. As world renowned Czech novelist and perennial candidate for the Nobel Prize in Literature Milan Kundera famously put it, "The struggle of man against power is the struggle of memory against forgetting." 166 This means, of course, that political power plays a crucial role in shaping public discourses about the past, and that challenging these discourses is necessary in order to alter how the past is represented and remembered. The debates surrounding Gross's books have undoubtedly demonstrated how historians can play a role in this process through their written work. As Peter Burke has argued, however, there are limits to what can be accomplished through writing and publishing. Indeed, though written scholarship can help to preserve inconvenient records that undermine or challenge nationalistic historical narratives that distort the past, it cannot stop the spread of these distortions. ${ }^{167}$ This seems quite plausible too; after all, even the most successful academic works often have a limited audience. Even if everyone could read and follow the writings of professional historians, however, there would still always be those who would remain unconvinced. It is necessary, therefore, to contemplate other ways of constructing collective memory. One of the most powerful tools for shaping memory are museums, which as Turkish Nobel laureate Orhan Pamuk remarked are the places where "Time

${ }^{166}$ Milan Kundera, The Book of Laughter and Forgetting (London: Penguin, 1983).

${ }^{167}$ Peter Burke, from "History as Social Memory," in The Collective Memory Reader, ed. by Jeffrey K. Olick, Vered Vinitzky-Seroussi and Daniel Levy (Oxford University Press, 2011). 
is transformed into Space." ${ }^{\prime 168}$ Indeed, museums represent public spaces dedicated exclusively to memory and meaning. There is now an extensive historiographical literature on museums, and scholars have labeled the diverse functions of museums in numerous ways—such as "memory palaces," "secular temples," or even "ceremonial time capsules." 169 Museums, ultimately, play an important role in the process of inventing (and reinventing) the past, and it should be no surprise why museums have become a paramount object of study for scholars of memory. Historical narratives are reified through the creation of museum exhibits, and the question of how to engage the past-including what is included or excluded in an exhibition, what is emphasized or deemphasized, etc.- - is the quintessential issue for any museum curator.

So naturally, therefore, the question of how to address the Polish-Jewish past and the legacy of anti-Semitism in Poland was an enormous problem for the Polin Museum of the History of Polish Jews when it was first conceptualized. Is it better, for instance, to focus exclusively on the history of anti-Semitism in Poland, culminating with the Holocaust and the near-complete destruction of Poland's once vast Jewish community? If so, how then should the controversial debates over the role of Poles in the Holocaust be represented? Or should the museum take a different approach to these issues? Ultimately, those in charge of the museum would opt for the latter solution. As should now be quite clear, the Memory Wars have involved a series of extremely divisive debates on Polish history. If the museum followed Gross's approach, i.e. to wage an all-out assault on Poland's national mythology, it is likely that many Poles would be instantly turned off. Furthermore, the apparent stagnation in the debates about and increasingly hostile reception to Gross's work in Poland suggests that a new approach to

\footnotetext{
${ }^{168}$ Orhan Pamuk, The Museum of Innocence (Alfred A. Knopf, 2009).

${ }^{169}$ Karen E. Till, "Reimagining National Identity 'Chapters of Life' at the German Historical Museum in Berlin," in Textures of Place: Exploring Humanist Geographies (Minneapolis: University of Minnesota Press, 2001), 275.
} 
these issues could prove useful — especially if the goal is to attract visitors and to change the way those visitors understand and interpret history, which is presumably the goal of virtually all museums. Thus, the Polin Museum of the History of Polish Jews has sought to tell a very different — and seemingly neglected—story: how Polish Jews actually lived. Poland was once the epicenter of European Jewish life, yet the Memory Wars suggest that the history of Polish Jews is a story of absolute carnage and utter destruction. But Polish Jews did more than die. For hundreds of years, indeed, they lived — often peacefully with their Polish neighbors—and built vibrant communities and a unique culture. As the current director, Dariusz Stola, explained the museum's central goal, "If someone kills me tomorrow, I would want people to remember my life, not just my death. Our basic idea is to show that Jewish life in Poland was richer than the six years of the Holocaust." ${ }^{\prime 17}$ In the end, in order to adequately address the Polish-Jewish past, it is necessary to go beyond the horrors of Auschwitz or Jedwabne. The Polin Museum, ultimately, even goes beyond the very issue of Polish-Jewish relations in its effort to depict Polish-Jewish history, which is just one layer of this multifaceted history.

Of course, none of this means ignoring the dark side of Polish-Jewish history. As Christopher H. Smith stated, the Polin Museum was intended to "(commemorate) and (remember), with great sorrow, the three million Jews who died during the Holocaust and World War II, but also (to celebrate) the rich thousand years of Polish Jewish life."171 Ewa JunczykZiomecka, a former Polish secretary of state, further added that the museum would reclaim a

170 Ofer Aderet, "Watch: New Warsaw Museum tells story of Poland's Jews," last modified October 28, 2014, http://www.haaretz.com/jewish-world/jewish-world-news/.premium-1.622797

${ }^{171}$ Christopher H. Smith, "Museum of the History of Polish Jews: Hearing before the Commission on Security and Cooperation in Europe: One Hundred Tenth Congress: Second Session" (Washington DC, U.S. Government Printing Office, 2011), 3. 
"magnificent history" that both Poles and Polish Jews could "learn and cherish." "172 Moreover, Junczyk-Ziomecka viewed the establishment of the Polin Museum as a moral obligation that could only be fulfilled in the new and democratic Poland. ${ }^{173}$ None of this is intended to imply that this is the "correct" way to portray the history of Polish Jews. Memory should be pluralistic and open to a numerous presentations. States that elevate a single hegemonic interpretation of history tend to be excessively authoritarian or totalitarian. A more confrontational approach to the topic, however, ought not to be favored solely on pragmatic grounds. Rather than pose a needlessly provocative challenge to its visitors, the Polin Museum seeks to "(encourage) discussion and (build) awareness among opinion leaders, the media and the general public" in the hopes that they will learn to understand that "the history of Poland is not complete without the history of Polish Jews." 174 This is undoubtedly a noble yet extraordinarily challenging goal. And with expectations of hundreds of thousands of annual visitors and beautiful modern exhibits, the museum appears to be off to a good start.

The Polin Museum of the History of Polish Jews is located in the heart of the former Warsaw Ghetto, the site of a fierce Jewish uprising in 1943 against the Nazis that resulted in hundreds of thousands of Jewish fatalities. Furthermore, the vast majority of the Warsaw Ghetto's Jewish inhabitants who did not die in the uprising perished at Nazi death camps like Treblinka. Contrasting sharply with this dark history, the museum is located within a stunning one hundred million dollar postmodern building designed by the Finnish architects Rainer Mahlamäki and Ilmari Lahdelma, who won a major international competition to design the

${ }^{172}$ Ewa Junczyk-Ziomecka, "Museum of the History of Polish Jews: Hearing before the Commission on Security and Cooperation in Europe," 5.

${ }^{173}$ Ibid, 4-5.

${ }^{174}$ Joint Prepared Statement of Ewa Junczyk-Ziomecka and Ewa Wierzynska, "Museum of the History of Polish Jews: Hearing before the Commission on Security and Cooperation in Europe," 26. 
museum. ${ }^{175}$ When asked why the architects opted for such a beautiful design, Mahlamäki acknowledged the unspeakable horrors of the Holocaust but hoped that the museum's beauty could "refer to a better future" between Poles and Jews. ${ }^{176}$ To further reinforce this message, it is worth noting that the museum came about through a collaborative effort by both Poles and Jews - though admittedly with considerable international assistance. Still, former Polish president Aleksander Kwaśniewski and Shimon Peres, a former Israeli President and Prime Minister, both helped to oversee this massive project. ${ }^{177}$ This level of cooperation between Poles and Israelis suggests a willingness to work together and a recognition that the memory of Polish Jews can and should be addressed by both sides. Hopefully the museum can help to build the foundations for a better future of Polish-Jewish relations.

The Polin Museum's Core Exhibition, which was created by a team of scholars and curators led by Barbara Kirshenblatt-Gimblett, seeks to reconstruct centuries of Polish Jewish life in myriad ways. ${ }^{178}$ Going all the way back to the Middle Ages, the museum traces the origins of Jewish life in Poland and explains how any why Poland became the heart of Jewish culture in Europe. Moreover, the museum reveals the complexity of Polish-Jewish history and emphasizes the many variations in Jewish social and religious life throughout the centuries. ${ }^{179}$ Finally, the museum emphasizes personal stories; consequently, the displays contain numerous individualized accounts - from rabbis, scholars and chroniclers, merchants, housewives and

\footnotetext{
175 “Muzeum Historii Żydów Polskich,” last modified February 2, 2011, http://szrm.pl/inwestycje/zrealizowane/muzeum-historii-zydow-polskich-3/

${ }^{176}$ Aino Frilander and Heikki Aittokoski, “Arkkitehtuurin ensimmäinen Finlandia-palkinto: Rainer Mahlamäen puolanjuutalaisen historian museo Varsovassa," last modified November 4, 2014, http://www.hs.fi/kulttuuri/a1305894111681.

177 “Muzeum Historii Żydów Polskich,” http://szrm.pl/inwestycje/zrealizowane/muzeum-historii-zydowpolskich-3/

178 “Core Exhibition - Grand Opening October 28, 2014,” http://www.polin.pl/en/exhibitions/coreexhibition-grand-opening-october-28-2014. 179 Ibid.
} 
many others - of the rich, diverse historical experiences of Polish Jews. ${ }^{180}$ Perhaps the Polin Museum's most impressive display is the partially recreated Gwoździec Synagogue, which was located in present-day Ukraine and did not survive the Second World War, including the Synagogue's intricately painted ceiling and timber roof. Ultimately, the museum is by far the most serious attempt to understand and recreate Polish-Jewish life in postwar Poland's history. Because the museum will likely become one of the country's top attractions, moreover, it has the power to help significantly reshape memory about the historical experience and role of Polish Jews in the coming years - not just in Poland but throughout the world, as many international visitors are expected annually.

In general, the reception of the Polin Museum has been mostly favorable throughout the Polish media. Wiktor Ferfecki, for example, writing for Rzeczpospolita, which is widely known as a conservative paper in Poland, argued that the Polin Museum constitutes a breakthrough in the presentation of the Polish-Jewish past—-though admittedly Ferfecki's primary concern seems to be how Poles are perceived abroad. ${ }^{181}$ Similarly, in Gazeta Wyborcza, a more liberal newspaper that has often been supportive of Gross throughout the Memory Wars, the museum has also been generally portrayed in a positive light. ${ }^{182}$ The Polin Museum has also been well received in Israel. For instance, Israel's current President, Reuven Rivlin, attended the opening ceremony of the museum. For Rivlin the history of Polish Jews is a crucial part of Jewish heritage: "As a Jew, even if you were not born in Poland, the very name, Poland, gives rise to a

180 Ibid.

${ }^{181}$ Wiktor Ferfecki “Potrzebne Muzeum Żydów," last modified October 29, 2014, http://www.rp.pl/artykul/1150204,1152982-Potrzebne-Muzeum-Zydow.html

182 See, for instance, Roman Pawłowski “Otwiera się interaktywne Muzeum Historii Żydów Polskich. Czyli pierwsze muzeum historii Polski," last modified October 27, 2014, http://wyborcza.pl/1,75475,16869612,Otwiera_sie_interaktywne_Muzeum_Historii_Zydow_Polskich_.html 
shuddering in your body and a longing in your heart." ${ }^{\text {"183 }}$ Rivlin, moreover, praised Poles for their willingness to confront the dark history of Jedwabne. ${ }^{184}$ President Bronisław Komorowski also attended the opening ceremony and emphasized "the great contribution of (Polish Jews) to Polish culture." 185 Nevertheless, the museum also has its critics. Konrad Matyjaszek, writing for Kultura Liberalna, has criticized the Polin Museum for failing to adequately address Polish antiSemitism and other troublesome aspects of the Polish-Jewish past. ${ }^{186}$ One must, however, consider such criticisms in the context of what is actually possible in contemporary Poland. One certainly could unveil a hypothetical museum dedicated exclusively to the darkest aspect of the history of Polish Jews. But, honestly, how would that actually be received in Poland? Would such a museum — assuming it could even secure funding — be able to contribute to a constructive dialogue on the past? Or would it simply further exacerbate the already vexing, toxic disputes over the memory of the Holocaust and the memory of Polish Jews? Furthermore, it must be noted that the Polin Museum does actually include information on the Holocaust and various pogroms before, during and after the Second World War, though such displays are admittedly far from the museum's central focus. One should not conceive of the Polin Museum as offering a challenge to Gross or any other critic of Polish national memory. On the contrary, the museum ought to be conceived as part of a broader process of reassessing the Polish-Jewish past that complements previous challenges. Viewed from this vantage point, the Polin Museum offers an invaluable contribution to the reconstruction of Polish collective memory.

\footnotetext{
${ }^{183}$ Greer Fay Cashman, "Rivlin in Warsaw: Saga of the Jews did not begin in Poland nor did it end in Auschwitz," last modified October 28, 2014, http://www.jpost.com/Diaspora/Rivlin-in-Warsaw-Jews-wereremoved-from-Poland-but-Poland-was-not-removed-from-the-Jews-380070

${ }^{184}$ Ibid.

185 Ibid.

${ }^{186}$ Konrad Matyjaszek, "Polinizacja historii. O wystawie stałej Muzeum Historii Żydów Polskich,” last modified March 24, 2015, http://kulturaliberalna.pl/2015/03/24/konrad-matyjaszek-mhzp-wystawa-stala-recenzja/
} 


\section{Polling Data}

There is, of course, a normative question that up until now has not been adequately addressed: does the contemporary Polish memory of the Holocaust and the Polish-Jewish past actually need to be altered? This normative question, it must be noted, is inextricably linked to an empirical one: namely, how have Poles actually viewed the Holocaust throughout the Memory Wars? Additionally, in order to assess such questions, one must consider the scope and extent of anti-Semitism throughout present-day Polish society. Perhaps the best way to explore such questions is to examine the evidence from polling data, which frequently provides a window into the general public's attitude toward controversial issues. While it is undoubtedly the case that public opinion polls are sometimes easy to manipulate, this is not a compelling argument against their use; instead, this is a crucial realization that helps to highlight the importance of interpreting polling data in a careful and responsible manner.

Between December 29, 1994 and January 5, 1995 Demoskop, a Swedish company known for its opinion polls, carried out a study for the American Jewish Committee to assess Polish attitudes toward the Holocaust. ${ }^{187}$ The information was gathered through face-to-face interviews with 1,145 Poles. The data Demoskop compiled was broken down in terms of gender, education level, age and religion. Transnational comparisons were also sometimes given. In general, the study found that Poles had a relatively high degree of factual knowledge of the Holocaust, but it also found that many Poles strongly identified with a view of Polish history that equated Polish victimization with Jewish suffering during the war. ${ }^{188}$ Moreover,

\footnotetext{
${ }^{187}$ Renae Cohen and Jennifer Golub. "Knowledge and Remembrance of the Holocaust in Poland." Working Papers on Contemporary Anti-Semitism. American Jewish Committee (1995).

${ }^{188}$ David Singer, foreword to "Knowledge and Remembrance of the Holocaust in Poland," by Cohen and Golub. Working Papers on Contemporary Anti-Semitism. American Jewish Committee (1995).
} 
whereas $67 \%$ of respondents believed that many Poles participated in efforts to save Jews during the Holocaust, only $11 \%$ thought that many Poles had participated in the persecution of Jews during the Second World War. ${ }^{189}$ This asymmetry reinforces the assertion by Gross and other critics of Polish memory that many Poles have far too often dismissed allegations of Polish complicity or collaboration with the Holocaust while actively cultivating a much more virtuous wartime narrative that celebrates Polish heroism and sacrifice. Many other questions illustrated attitudes toward Jews and the Holocaust that, at least when the study was carried out, also seemed problematic. For instance, to further reinforce the earlier assertion on the perceived equivalence of Polish and Jewish victimization, 28\% of respondents claimed that Poles had suffered more than Jews; by contrast, only $29 \%$ of respondents thought that Jews had suffered more, whereas $40 \%$ viewed Polish and Jewish wartime experiences as about the same. ${ }^{190}$ Others reported that they did not know or gave unrelated responses. In reply to the question, "Did Poles do enough to help Jews during the Second World War?" 49\% of respondents maintained that Poles had done enough, and $26 \%$ alleged that they had done as much as possible given the circumstances, whereas merely $15 \%$ claimed that Poles had not done enough to aid their Jewish neighbors. ${ }^{191}$

The Demoskop study also asked Poles whether it was good for the country that there were far fewer Jews in present-day Poland than prior to the Second World War. In response, only $5 \%$ thought this was a bad development, whereas a disturbing $35 \%$ of those polled maintained that this was good. Precisely $51 \%$ of respondents viewed the situation as neither good nor bad, and the remaining 9\%, finally, claimed that that they did not know if it was good

\footnotetext{
${ }^{189}$ Cohen and Golub, "Knowledge and Remembrance of the Holocaust in Poland," 30-31.

190 Ibid, 28.

191 Ibid, 29.
} 
or bad or gave unrelated answers. ${ }^{192}$ A similar study, conducted by Wprost, which was carried out after the release of Neighbors, asked the same question and came to an even more troublesome conclusion: half of all Poles thought it was good that contemporary Poland had fewer Jews than pre-war Poland. ${ }^{193}$ Returning to the Demoskop study, Poles were also asked whether they wanted Jews in their neighborhoods. Only $6 \%$ of respondents said they wanted Jewish neighbors, $40 \%$ said that it would not matter either way, and unfortunately $30 \%$ said that they would rather not have Jews in their community. ${ }^{194}$

Of course, it ought to be noted that not all the Demoskop's findings were negative. As mentioned a moment ago, the study concluded that Poles had a relatively high degree of awareness of basic Holocaust facts. Additionally, Poles strongly endorsed the importance of memory. When asked whether it was time to put the memory of Hitler's extermination of the Jews behind them, a resounding $89 \%$ of Poles said that it was necessary to keep remembrance strong, whereas only $10 \%$ thought that it was time to forget the Holocaust. ${ }^{195}$ Nevertheless, this figure could be partially explained by Poles' commitment to their own national narrative of victimization. If it was time to forget about Nazi crimes against Jews, then surely it would also be time to forget about Nazi (or Soviet) crimes against Poles. Furthermore, when asked whether the Nazi extermination of Jews was no longer relevant today because it happened 50 years ago, $25 \%$ of Poles strongly disagreed and $43 \%$ mostly disagreed. Only $6 \%$ of Poles, conversely, strongly agreed, but $22 \%$ reported that they mostly agreed that the Shoah was no longer relevant.

192 Ibid, 37.

${ }^{193}$ Alvin Rosenfeld. Facing Jedwabne (New York: American Jewish Committee, 2002), 6.

${ }^{194}$ Interestingly, many other many ethnic groups - including Russians, Romanians, Ukrainians, Arabs, Gypsies, Belarussians and Africans-actually fared worse than Jews on this question. In the case of Gypsies and Romanians especially, the study found that Poles were much more hostile to the idea of these groups as neighbors than Jews; Cohen and Golub, 39.

${ }^{195}$ In countries like Hungary or the former Czechoslovakia, people were far more likely to say that it was time to forget about the Holocaust than in Poland; Ibid, 18-19. 
Once again, these findings can be interpreted as a desire to commemorate Poland's own suffering, but it is at least interesting to see that many Poles recognized the importance of remembering the Holocaust - particularly if it was the Nazis, and the Nazis alone, that were being accused of evil deeds. It would be undoubtedly interesting to see a similar study on Jedwabne. It is likely that many Poles would deem the pogrom no longer significant — though it must be emphasized that the Demoskop study predated Gross and Neighbors.

Moreover, the study revealed that $69 \%$ of Poles believed that it was important to know about and understand the Nazi extermination of Jews, and 17\% of respondents claimed that such knowledge and understanding was essential. Only $11 \%$ deemed it somewhat important, whereas just $1 \%$ of Poles said that it was not important at all. ${ }^{196}$ The study, finally, demonstrated that outright Holocaust denial was virtually nonexistent in Poland during the mid-1990s. Just $1 \%$ of respondents thought that it was possible that the Holocaust had never occurred; by contrast, $96 \%$ of Poles maintained that they felt certain it had happened. ${ }^{197}$ Given that Poland once had Europe's largest and most vibrant Jewish community, this is hardly surprising - especially since Poland was home to many of the most notorious Nazi death camps like Auschwitz, Treblinka, Bełżec and Chełmno. Indeed, it would be absolutely absurd and impossible for Polish Holocaust deniers to explain away the disappearance of Poland's Jews. Furthermore, Holocaust denial— like in many European states which frequently have less libertarian conceptions of free speech than, say, the US - is a crime in Poland. ${ }^{198}$ Yet it is interesting to note that, while Poles

${ }^{196}$ Ibid, 22.

${ }^{198}$ It is necessary to mention that the language of the law outlawing Holocaust denial in Poland emphasizes, first and foremost, crimes committed against persons of Polish nationality; Jews are not mentioned in the legislation, but they are still implied by the law, which also outlaws denying Nazi crimes committed against Polish citizens of other nationalities during WWII; "Ustawa z dnia 18 grudnia 1998 r. o Instytucie Pamięci Narodowej - Komisji Ścigania Zbrodni przeciwko Narodowi Polskiemu,” http://isap.sejm.gov.pl/DetailsServlet?id=WDU19981551016 
universally rejected any denial of Nazi crimes, just five or six years after this study's completion many Poles would end up denying the truth about Jedwabne when it first came to light.

With all that said, while this poll suggests that many Poles in the mid-1990s embraced a nationalistic view of history and harbored anti-Semitic attitudes, it necessary to approach these findings with a degree of caution. Social scientists have extensively documented the many problems inherent in public polling. Very subtle issues - such as the wording of the questions posed or the order of the questions - can trigger vastly different answers. Consider, for instance, the question that asked whether it was a negative development that contemporary Poland had far fewer Jews than pre-war Poland, which only 5\% of respondents viewed as an unfortunate development while another 35\% viewed contemporary Poland's dearth of Jews as a positive development. If this question had emphasized that the missing Jews had been systematically slaughtered by the Third Reich, it is quite plausible that the statistics would have looked very different. Nevertheless, it is important to recognize that this empirical data—taken in conjunction with other relevant evidence - helps to bolster the inexorable conclusion that many Poles really have had a serious problem confronting the Polish-Jewish past.

Of course, Poland is not the same country it was in the mid-1990s. Consequently, in order to get a more accurate portrayal of the current situation, more recent data must also be analyzed. Is there any evidence that compared to the Demoskop study, which was conducted during the early stages of the Memory Wars, anti-Semitism in Poland is declining? A series of studies, which were carried out by the Polish sociologist Antoni Sułek between 2002 and 2010, provide some reason for optimism. ${ }^{199}$ In order to shed light on Polish attitudes toward Jews,

\footnotetext{
${ }^{199}$ Wojciech Szacki, “Sondaż: Nie boję się ciebie, Żydzie,” last modified February 7, 2011, http://wyborcza.pl/1,76842,9063597,Sondaz_Nie_boje_sie_ciebie_Zydzie.html
} 
Sułek's study relied on polls that asked respondents a series of questions and compared their responses over the eight-year period. In 2002, for example, when asked which (if any) minorities had too much influence in Poland, $19 \%$ of Poles mentioned Jews, but the data suggested that this number had declined to just $6 \%$ by 2010 . Similarly, when asked directly about the role of Jews in Poland, $43 \%$ of respondents claimed that Jews had too much power and influence in Polish affairs; however, according to the 2010 study, that number had decreased to 22\%. The trend, according to Sułek's interpretation, is undeniable: anti-Semitism in Poland is declining. This trend, moreover, can be seen in all age groups. But Sułek's conclusion has been subjected to criticism. For Ireneusz Krzeminski, who is also a sociologist, Sułek's study is onesided. Indeed, Krzeminski points out that it fails to adequately capture the nature of antiSemitism, which goes beyond the belief that Jews have secret power and influence within society. ${ }^{200}$ For many Polish anti-Semites, national identity and political consciousness are deeply intertwined with their anti-Semitic attitudes. Such attitudes are pervasive in Poland, argues Krzeminski, and one only needs to listen to Radio Maryja, a right-wing ultranationalist radio station based in Torun, in order to perceive this basic truth. ${ }^{201}$

\section{A 2013 opinion poll, which was conducted by the University of Warsaw's Center for} Research on Prejudice, also came to a less optimistic conclusion than Sułek. ${ }^{202}$ According to this study, anti-Semitism is deemed a "persistent problem" in contemporary Polish society. ${ }^{203}$

\section{Ibid}

${ }^{201}$ Many individuals — both inside and outside Poland — would agree with Krzeminski's characterization of Radio Maryja. The station has, for example, been described as "blatantly anti-Semitic" by the US State Department; "Contemporary Global anti-Semitism: A Reports Provided to the US Congress," http://www.state.gov/documents/organization/102301.pdf

${ }^{202}$ Michał Bilewicz, Mikołaj Winiewski and Wiktor Soral, “Antisemitism in Poland 2013: Research Report based on Polish Prejudice Survey II," http://cbu.psychologia.pl/uploads/f_winiewski/PPS2\%20raporty/raport_antysemityzm_ang.pdf

$$
203 \text { Ibid. }
$$


Furthermore, the prevalence of anti-Semitism—which is divided into three different forms: belief in Jewish conspiracies, secondary anti-Semitism (defined as the view that Jews have abused the Holocaust and are themselves responsible for anti-Semitic attitudes), and traditional antiSemitism (defined as the view that Jews are guilty of blood libel or deicide) — has not fluctuated significantly in recent years. ${ }^{204}$ Indeed, the authors found that traditional anti-Semitism had slightly increased over the past several years, whereas the other two forms of anti-Semitism had declined very minimally. Other recent polls have shown that not insignificant minorities of Poles would refuse to work with a Jewish coworker and that many Poles would not be willing accept the marriage of a relative to a Jew. ${ }^{205}$

The findings of the 2013 opinion poll were even presented to the Sejm-where the study was generally well received by members of the Polish parliament. Some members of the Sejm even suggested potential education measures intended to help fight anti-Semitic prejudices in Poland. ${ }^{206}$ Ultimately, the evidence is unclear on what role the Memory Wars have played in shaping the attitudes of ordinary Poles. In fact, the data on anti-Semitism in contemporary Polish society is somewhat mixed, and further research is undoubtedly needed to help shed light on whether and to what extent Polish attitudes toward Jews have changed over the last several years. As Sułek's study demonstrates, of course, there is some reason-though by no means any decisive reason - to see an improvement in Polish attitudes toward Jews since the debates over the Polish-Jewish past have reached their climax. Nevertheless, the findings of the Center for Research on Prejudice suggest that attitudes are changing perhaps more slowly. With that said, even many of the troublesome findings of recent public polling data-such as the recent finding

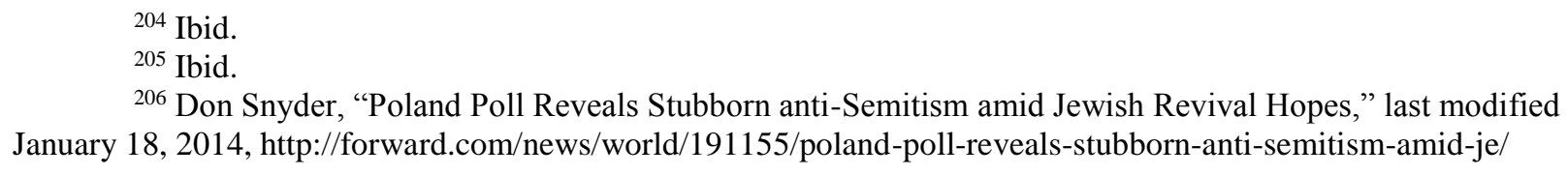


that only $14 \%$ of Poles would want a Jewish neighbor ${ }^{207}$ —are still technically improvements over the findings of the Demoskop study. This perhaps suggests, at the very least, an improvement from the mid-1990s to the present day. It would be too reductionistic to say that this is solely the result of Poland's attempt to wrestle with its history; after all, there are surely myriad causes that help to shape public opinion. Nevertheless, the process of engaging the Polish-Jewish past—including the darkest, most troubling aspects of this history—is likely a crucial part of this phenomenon. By recognizing the historical reality of anti-Semitic violence in Poland, many Poles have been able to recognize their own anti-Semitic prejudices and beliefs, which is undoubtedly the first step toward changing attitudes. Ultimately, the data overwhelmingly agrees on one point: anti-Semitism is still a major problem in contemporary Poland. Though it is difficult to gauge the exact numbers, there are various estimates that suggest that the prevalence of anti-Semitic attitudes is quite high across the country. ${ }^{208}$ Such views are unlikely to disappear completely in the foreseeable future, but hopefully new efforts to address the Polish-Jewish past—-such as the Polin Museum of the History of Polish Jews—will help to continue to reduce anti-Semitism in Poland.

${ }^{207}$ Bilewicz, Winiewski and Soral, "Antisemitism in Poland 2013," http://cbu.psychologia.pl/uploads/f_winiewski/PPS2\%20raporty/raport_antysemityzm_ang.pdf

208 The director of the Polin Museum, for example, the aforementioned Dariusz Stola, estimates that $25 \%$ of Poles are anti-Semites; Don Snyder, "Poll reveals anti-Semitism in Poland, renews debate over hate-speech laws," last modified November 16, 2014, http://www.foxnews.com/world/2014/11/16/poll-reveals-anti-semitism-inpoland-renews-debate-over-hate-speech-laws/ 


\section{Chapter Six: Moral Responsibility and Polish-Jewish Reconciliation}

Much of the existing literature analyzing and debating the Polish-Jewish past falls into a common trap. All too often there are sweeping statements made without proper argumentation or elaboration. Indeed, it is crucial to recognize that there is more at stake in the Memory Wars than memory. The manner in which history is represented and remembered, of course, is undoubtedly a crucial aspect of these debates and the point here is not to minimize its significance; nevertheless, these debates are also infused with normative questions that are routinely ignored or at least not treated with the seriousness they deserve by scholars. Ultimately, if there is going to be substantial progress made on the debates over the PolishJewish past, there must be a careful, rigorous analysis of collective moral responsibility; it simply is not helpful to presuppose the veracity of this concept without any clarification or explication.

The notion of collective moral responsibility has profound implications for the Memory Wars. Even when Polish scholars accept the reality of significant Polish participation in, say, the Jedwabne pogrom, there is still a conversation to be had about what this means for contemporary Polish society. Should Poles who had nothing to do with this atrocity feel badly about it? Is there a sense in which modern-day Poles are culpable for this egregious crime? For many of Gross's critics the answer to such questions is a resounding no, whereas many of those who support a reassessment of the Polish-Jewish past disagree profoundly, yet the discussions on this issue often suffer from a lack of analytical clarity. Indeed, many who have addressed the PolishJewish past —including scholars, journalists and political figures — have not done themselves any favors by failing to seriously engage with the underlying philosophical issues here. Consider, for example, a handful of Jerzy Turowicz's assertions, which were by no means exceptional, in 
response to issues raised by Błoński: "Those among us who have never been anti-Semites and who may have fought against it, cannot nevertheless absolve ourselves totally from the collective moral responsibility for the anti-Semitism which was so widespread in our country."209

Interestingly, Turowicz seemed to offer no real arguments for these claims. On the contrary, these remarks instead were apparently based on unexamined philosophical presuppositions. Is it really the case that those who reject anti-Semitism and even those who fought against it are nevertheless partially responsible for the prevalence of anti-Semitic attitudes in Poland? If so, why and in what sense?

The point here is not necessarily to disagree with the sentiments outlined by Turowicz; instead, the point is to highlight one of many examples of the way in which unexamined normative claims often slip into these debates and impede progress on these issues. The scholar Piotr Forecki, for example, has asked whether the debates over the Polish-Jewish past have constituted a "moral purification" of Polish society. ${ }^{210}$ Of course, such language presupposes that there is a need for moral purification in the first place. But what exactly is moral purification anyway? And when is it necessary? This is precisely the language that many Poles - some of whom even accept that the history of Polish Jews is deeply problematic — find objectionable. Moreover, because they view those who challenge Polish memory as condemning the entire Polish nation, many Poles are often exceptionally hostile to counter-narratives. This partially accounts for the often disproportionate responses that inevitably arise when the PolishJewish past is brought up in contemporary Poland. Indeed, in much of the literature reassessing

\footnotetext{
${ }^{209}$ Polonsky, introduction to My Brother's Keeper?, 18.

${ }^{210}$ Forecki, 266.
} 
the Polish-Jewish past, even when such views are not made explicit, there is a failure to seriously engage with the moral issues that are inextricably linked to these debates.

Gross dedicates only a handful of pages to collective moral responsibility in Neighbors, and his discussion of the issue is not exactly nuanced; nevertheless, he provides some helpful insights. Interestingly enough, Gross offers at least a superficially explicit rejection of the notion of collective responsibility. ${ }^{211}$ For Gross, indeed, for every atrocity “only a specific murderer or group of murderers is responsible." 212 Yet Gross also asserts that individuals cannot arbitrarily pick and choose their history. If individuals constitute nations, and if nations have a genuine link to their past triumphs, then nations must also have a genuine link to their past shortcomingsergo, individuals must be connected to those shortcomings too. Just as individual Poles celebrate Chopin and Copernicus, Gross maintains, they must also learn to lament the actions of Laudański and Karolak, two of the perpetrators of the Jedwabne massacre. ${ }^{213}$ For they belong to Polish heritage just as much as Poland's heroes, and thus they too have a place in Polish collective identity.

Gross's views are mostly plausible, yet it is curious that he seems to want to sneak in collective responsibility through the back door. On the one hand, he openly disavows the notion, but on the other hand his argument seems to endorse collective blame. Clearly a more careful analysis is needed. Of course, it ought to be pointed out that there are many scholars who have argued extensively that there cannot be collective moral responsibility. ${ }^{214}$ Many of these critics

${ }^{211}$ Gross, Neighbors, 89. A very similar but more nuanced view is argued for in Farid Abdel-Noir, "National Responsibility," Political Theory 31, no. 5 (October 2003).

${ }^{212}$ Gross, 89.

213 Ibid, 89-90.

${ }^{214}$ Recall that this was the view asserted by Chodakiewicz in his criticism of Golden Harvest; indeed, the nature of moral responsibility was claimed to be "mea culpa" rather than "nostra culpa." For an interesting classic philosophical defense of this view, see H.D Lewis, "Collective Responsibility," The Journal of the Royal Institute of Philosophy 23, no. 84 (January 1948). For a more recent defense of this position, see Steven Sverdlik, "Collective 
have attacked the notion for a variety of reasons and have even challenged the coherence of the concept. Indeed, collective responsibility is often said to be impossible because groups —unlike individuals_-lack moral agency and intentionality, which are conceived as prerequisites for genuine moral responsibility. Hence, it is frequently argued, groups cannot be held praiseworthy or blameworthy for their actions; instead, only individual members of groups can be justly praised or blamed. ${ }^{215}$ This characterization of moral responsibility, however, is confused and often based on irrelevant concerns. ${ }^{216}$ It is arguably even anachronistic. In the modern world individual actors are often constrained by institutions, and these various institutions — such as nation-states, for example — also make actions possible that no single individual (or even group of individuals) could accomplish in isolation. Therefore, it is necessary to analyze the ethics of collectives - i.e., the rightness or wrongness of a given action taken by a group - in order to have a comprehensive account of moral responsibility. There is ultimately nothing particularly paradoxical about this either; individuals engage in this behavior on a daily basis when, e.g., they praise non-profit organizations or charities for their moral triumphs and condemn governments and corporations for their moral failings.

With that said, there is still an interesting issue that arises: once the coherence of collective moral responsibility is acknowledged, what about the case of the Polish-Jewish past more specifically? How is it possible to assess the collective moral responsibility of Poles for

\footnotetext{
Responsibility," Philosophical Studies: An International Journal for Philosophy in the Analytic Tradition 51, no.1 (January 1987).

${ }^{215}$ Marion Smiley, “Collective Responsibility,” Stanford Encyclopedia of Philosophy, last modified June 14, 2010, http://plato.stanford.edu/entries/collective-responsibility/\#1

216 There are obscure metaphysical reasons that some philosophers do not wish to accept the concept of collective responsibility - specifically because much of the philosophical discussion of moral responsibility more generally is connected to the debates over free will and determinism. It is often believed that, if determinism can be shown to be compatible with moral responsibility, then free will is compatible with determinism. But disentangling moral responsibility from individual agency creates problems for these debates; Ibid.
} 
crimes committed decades ago? In general, when discussing the collective responsibility for crimes from different eras, matters are always more complex. As a matter of principle, the further back in history the crime was committed, the less it makes sense to ascribe collective responsibility to a national group. On this view contemporary Americans share a much higher degree of moral responsibility for the egregious war in Iraq than for the perhaps even more horrific war in Vietnam. Yet the passage of time is not the only factor to consider. For instance, when the morality of American slavery is assessed, it is obviously necessary to consider the legacy of both slavery and racism in the United States, which still has a profound impact on the lives and economic prospects of African Americans. Moreover, when considering the ethics and the history of imperialism, it is crucial to assess how Western states have benefited - and in some ways continue to benefit—-from dominating weaker and less developed societies. Thus, when considering collective moral responsibility for historical crimes, it is important to recognize the impact of the crime and whether and to what extent this impact is still felt in the contemporary world.

What about the case of the Polish-Jewish past then? Well, the impact here is quite substantial: the almost complete eradication of Poland's once vast Jewish community. Poles, it must be stressed, were not the primary actors in this crime. The Nazis were- and always will be - the primary butchers of European Jewry, and Germans undoubtedly carry the bulk of moral responsibility. Nevertheless, their crime would have been impossible without the complicity or collaboration of millions across Europe. How many countless individuals ignored the plight of their Jewish neighbors? How many aided Germans when they sought to round up Jews? And in the very worst cases, how many individuals actually participated in the slaughter of Jews? Historians have shown that such cases were far from rare or exceptional. It is obviously not 
surprising that Poland has become such a critical country in the debates on the Holocaust and national responsibility throughout Europe; after all, Poland was home to half of the victims of the Holocaust. It also must be stressed, however, that Poles were by no means unique here. There is plenty of blame to go around. And there are plenty of countries where atonement is badly needed.

Regardless, there is an even more important kind of moral responsibility that needs to be incorporated into this discussion. It is one thing to say that Poland is blameworthy in some sense for its past. It is another thing, however, to say that contemporary Poles have a moral obligation to keep the past alive. As the philosopher Jeffrey Blustein points out, there is a "moral imperative to remember (certain historical events) accurately, to expose fabrication, obfuscation, and manipulation, and to preserve for and pass on to succeeding generations the truth about what really happened." 217 Indeed, the importance of remembering cannot be overstated here. The obligation to remember the dark past is a crucial realization that all societies must come to terms with. Given that Blustein is right on this central point, critics of Polish national memory like Gross or Błoński embarked upon a truly virtuous pursuit: to expose the weaknesses of Poland's nationalistic historical narratives and reveal some of the horrific crimes that have taken place against Poland's Jews. This troublesome history, which for too long went unnoticed and undocumented, has now found itself at the subject of a massive and seemingly never ending series of debates, which I have designated the Memory Wars. But how should these reassessments of Polish history ultimately be assessed in moral terms? Has Poland been able to fulfill its obligation to remember? What would it even mean for Poland to fulfill this obligation? Would it mean that every single Pole ought to recognize the importance of remembering the 
Polish-Jewish past? Of course not. As Immanuel Kant famously pointed out, “ought” implies "can." 218 In order to assess this moral obligation, it is necessary to consider what is actually possible or feasible in Poland. Regardless of whatever future challenges are posed to Polish national memory, Poles are likely to remain extremely sensitive and defensive about this history, and this needs to be taken into account. While many Poles (perhaps even a majority) remain hostile to the core issues addressed by the critics of Polish national memory, this should not be used as the sole criterion for assessing the Memory Wars. Instead, it is important to look at how far Poland has come in discussing and debating these issues in just a few decades and to consider what might be possible in the future.

Of course, it is also important to recall that Poland truly suffered extraordinary losses during the Second World War, and there is certainly a moral obligation to keep this history alive too. The huge disparity in violence on the Western and Eastern Fronts was no coincidence; Hitler's wars against Poland and the Soviet Union were genocidal in nature. The Third Reich's goal was to acquire lebensraum in the east for the German people, who were presented as the Herrenvolk in Nazi propaganda, and this entailed a mass extermination of all so-called racial undesirables: Jews, Slavs, Gypsies, homosexuals, etc. ${ }^{219}$ Poles have both a right and obligation to remember these horrific crimes. But in the end, far too many Poles view any attempt to reassess the Polish-Jewish past as a threat to their own sacred history of oppression and victimization, and in fact use or instrumentalize this sacred history in order to dismiss or discredit the critics of Polish national memory. Yet it does not have to be this way. It must be

\footnotetext{
${ }^{218}$ Immanuel Kant, Religion within the Boundaries of Mere Reasons: And Other Writings (Cambridge University Press, 1999).

${ }^{219}$ Ultimately, the Nazi vision for the East—known as Generalplan Ost-would have required the extermination (often through starvation) or resettlement of millions across Central and Eastern Europe.
} 
recognized that Poles can be both victims and victimizers ${ }^{220}$; this does not have to be a simple binary distinction. History is always complex, and it is important to present those many nuances and complexities - even (perhaps especially) when they clash with national sensitivities. Nevertheless, far too many countries fail in their moral duty to keep the past alive. While Poles remain eternally divided on the Polish-Jewish past, the fact that such debates and discussions have occurred is undoubtedly a positive development. Far worse, indeed, would be to simply forget about Jedwabne or Kielce. Poles should be praised for their willingness to confront the demons of history and for being passionate about these issues; however, there are also undeniably disturbing tendencies that arise whenever the controversies over the Polish-Jewish past rear their ugly head. Ultimately, there are good reasons for both optimism and pessimism about the success (or failure) of the Memory Wars in terms of altering the attitudes of ordinary Poles. These debates are far from over, and much will depend on how these issues are presented to the Polish public in the future. With new ways of portraying this vexing history, such as e.g. the Polin Museum, which takes a less provocative approach to these issues, there is on balance probably more reason for optimism than pessimism.

\section{Polish-Jewish Reconciliation}

But what about the issue of Polish-Jewish reconciliation? Is it possible for Poles to finally put the past behind them? Is simply commemorating this dark, troublesome history — as many Poles have certainly done-enough? What if, as Avishai Margalit has argued, "memory breathes revenge as often as it breathes reconciliation"? Is it possible that "the hope of reaching catharsis through liberated memory might turn out to be an illusion"? ${ }^{221}$ Such a perspective might at first

\footnotetext{
${ }^{220}$ Gross himself actually argues for this view, Neighbors, 95-101.

${ }^{221}$ Avishai Margalit, The Ethics of Memory (Cambridge: Harvard University Press, 2002), 5.
} 
appear attractive; after all, numerous Poles, who perhaps would not have given the Polish-Jewish past much thought otherwise, have almost certainly been antagonized by the various mnemonic challenges to their history. As a consequence of these challenges, many Poles surely endorse a more nationalistic and anti-Semitic view of their past as a result of the Memory Wars. At the same time, however, many Poles have recognized the errors of history and have adopted a genuinely conciliatory tone toward Jews. Ultimately, if Polish-Jewish reconciliation is to be conceived as a genuinely analytically robust concept, it must be interpreted as something that is actually feasible. Not all Poles are going to want to be reconciled with Jews, and many Jews would undoubtedly be equally reluctant to accept any reconciliation with Poles. It is virtually impossible for Poles - or any other nation for that matter - to speak with a truly unanimous voice, and Poles can hardly be faulted for failing to do the impossible.

So how then should reconciliation be conceived? Regardless of Margalit's somewhat cynical speculation, many scholars agree that truth telling is necessary condition for reconciliation, but it is by no means a sufficient one. ${ }^{222}$ Political apologies are often also conceived as a crucial step in the process of reconciliation. ${ }^{223}$ Of course, the notion of an apology itself leads to conceptual confusion—an apology from whom exactly? Important political leaders? The majority of a country's population? The latter notion presents obvious problems. Poland, for example, is a country of roughly 38,000,000 individuals. Suppose that one day $19,000,000$ of those individuals agreed that it was necessary to sincerely apologize to Jews for the country's historic anti-Semitism, and the remaining half refused to offer such an apology. Now suppose that the following day one individual who had previously refused to

\footnotetext{
${ }^{222}$ Lina Radzik, "Reconciliation," Stanford Encyclopedia of Philosophy, last modified May 11, 2015, http://plato.stanford.edu/entries/reconciliation/\#TruTel

223 Ibid.
} 
apologize changed her mind. Would Poland's national apology all of the sudden become meaningful? Of course not. There can be no hard delineation at which point a nation's apology is really meaningful. Most scholars, indeed, view reconciliation as a scalar concept. ${ }^{224}$ What is needed is the concept of a collective apology — not an apology of individuals within a collective. Surely there can be no better representative to offer a collective apology than a legitimate and democratically elected head of state. This is precisely what happened when Aleksander Kwaśniewski apologized for Jedwabne. So is that sufficient? Some may argue that this apology, like perhaps most such apologies, was politically motivated and therefore not sincere. But then what would it take to convince such a critic that an apology was sincere? How could anyone truly know Kwaśniewski’s heart? And if a sincere collective apology cannot be offered even in principle, surely Poles cannot be blamed for failing to apologize.

Perhaps this theorizing needs to be more closely tethered to what actual Poles and Jews have said regarding the possibility of reconciliation. Paweł Śpiewak, the director of the Jewish Historical Institute in Warsaw, for example, points out that over the last few decades there has been an explosion of interest within Poland on the topic of Polish-Jewish relations, and that there are far fewer anti-Semitic voices entering these discussions than previously. Ultimately, he argues, real Polish-Jewish reconciliation is currently unfolding through the will of a number of activists, authors and a large public audience. ${ }^{225}$ Other Polish scholars—such as Michał Bilewicz, Anna Stefaniak and Marta Wikowska — take a slightly different perspective. Indeed, they show that young Poles still have a very confrontational attitude toward Jews, which is at least partially the fault of Poland's education system, and that alternative education opportunities

${ }^{224}$ Ibid.

${ }^{225}$ Paweł Śpiewak, "Reconciliation with the absent: Poles and Jews in democratic Poland," in Reconciliation in Bloodlands: Assessing Actions and Outcomes in Contemporary Central-Eastern Europe, ed. Jacek Kurczewski (Peter Lang, 2013), 95-96. 
offer perhaps the best chance for true reconciliation. ${ }^{226}$ For Margalit, the notion of forgiveness, which of course is also a necessary condition for reconciliation, requires overcoming resentment but not forgetting. ${ }^{227}$ So for the perhaps 15,000 Polish Jews who remain in the country a crucial question to ask is whether they still resent their Polish neighbors for the country's anti-Semitic past (and to a lesser extent present). Interestingly, many contemporary Polish Jews downplay the country's anti-Semitism and some argue that philo-Semitism may even be on the rise. ${ }^{228}$ Whatever the case, certainly more research is needed on Polish Jews to better understand their attitude toward these issues.

In the end, whether or not it has been truly achieved, it is evident that Poles have at the very least taken meaningful strides toward reconciliation, which admittedly is not the only desirable outcome of the Memory Wars. Even if reconciliation has not yet—or even cannot—be achieved, the unilateral pursuit of a more complete, truthful history is still a noble goal. While there are no easy answers when it comes to concepts like "collective responsibility" or "reconciliation," it is important to strive for clarity in these discussions. Both the accusatory and exculpatory literatures routinely employ moralistic language without carefully explaining how such language is defined or interpreted. This is not simply a matter of being philosophically reckless; indeed, this often exacerbates the controversies over the Polish-Jewish past and impedes serious dialogue. This chapter, of course, does not claim to have any final, definitive answers on these concepts, but instead it should be read as suggesting a more careful way of framing these important issues.

${ }^{226}$ Michał Bilewicz, Anna Stefaniak and Marta Wikowska, "Polish Youth Confronting the Jewish Past," in Reconciliation in Bloodlands, 109.

${ }^{227}$ Margalit, 208.

${ }^{228}$ Katka Reszke, Return of the Jew: Identity Narratives of the Third Post-Holocaust Generation of Jews in Poland (Brighton, MA: Academic Studies Press, 2013). 


\section{Conclusion}

Perhaps the latest battle in Poland's Memory Wars occurred in the aftermath of a speech by FBI director James Comey on April 15, 2015 at the Holocaust Memorial Museum's National Tribute Dinner. During his speech, which was intended to be a general assessment of human nature's propensity for evil, Comey said, 'In (the perpetrators') minds, the murderers and accomplices of Germany, and Poland, and Hungary, and so many, many other places didn't do something evil. They convinced themselves it was the right thing to do, the thing they had to do. That's what people do. And that should truly frighten us." ${ }^{229}$ Predictably, these comments provoked outrage in Poland. It is true, of course, that Comey's remarks do not tell the entire story. Poles were under Nazi occupation, and it is undoubtedly a terrible mistake to see Poles and Nazis as equal partners in the slaughter of European Jewry — but it is far from obvious that is what Comey was suggesting, and only a very uncharitable reading of his speech would suggest otherwise. In response to Comey, Ewa Kopacz, Poland's current Prime Minister, lamented those "incapable of presenting historic truth in an honest way" and claimed that "Poland was not a perpetrator but a victim of World War II." ${ }^{230}$ Even more bizarrely, Polish president Bronisław Komorowski remarked that Comey's comments reflected his “ignorance, lack of historical knowledge and possibly large personal aversion (toward Poles)." ${ }^{231}$ An apology was demanded for Comey's perceived "insult," which was eventually given by Comey. ${ }^{232}$ This was in part

${ }^{229}$ James Comey, "Why I require FBI agents to visit the Holocaust Museum," last modified April 16, 2015, The Washington Post, http://www.washingtonpost.com/opinions/the-scariest-lesson-of-theholocaust/2015/04/16/ffa8e23c-e468-11e4-905f-cc896d379a32_story.html

${ }^{230}$ Rick Lyman, "Poland Demands Apology Over F.B.I. Director's Holocaust Remarks, ” The New York Times, http://www.nytimes.com/2015/04/21/world/europe/poland-angry-james-comey-fbi-directorholocaust.html?_r=0

${ }^{231}$ Ibid; Komorowski's response, which seems particularly surprising given his earlier Jedwabne apology, makes at least some sense in the context of his campaign for reelection; however, Komorowski would eventually lose to Andrzej Duda of the right-wing Law and Justice Party.

232 "Szef FBI żałuje swojej wypowiedzi," last modified April 23, 2015, http://www.rp.pl/artykul/1195855.html. 
precipitated by a letter signed by the heads of numerous prominent Polish historical institutions, which repudiated Comey and reminded readers that Poland had been "divided between two murderous totalitarian regimes" and that Poles had "fought for our freedom and yours."233

The Polish-Jewish past remains as fiercely contested as ever. As the Comey affair demonstrates, the memory of the Second World War and the Holocaust will not likely fade away in the near future; instead, these memories will remain ultra-politicized and the source of continued debate and polarization. The Comey affair also shows that there is a need for clarity and caution before rushing to judgment. Given a charitable reading, which is placed into the context of Comey's actual speech, the remarks in question were perfectly reasonable. As Gross and others have shown, there really are cases of terrible anti-Semitic violence in twentiethcentury Polish history both before, during and after the Second World War that need to be addressed. There is a legitimate fear that the critics of Comey will obscure or undermine this important history. At the same time, however, there is a larger context within which to discuss Polish-Jewish relations. To reiterate once again, Poles indubitably were the victims of both Nazi and Soviet aggression. And many Jewish lives were spared as a direct result of Poles who risked their own lives — as well as the lives of their families - in order to shelter Jews. ${ }^{234}$ Despite this larger context, it hardly seems fair-particularly given the location of the speech — to expect the director of the FBI to have given a detailed exposition of Polish wartime history. The response in Poland was ultimately grossly disproportionate to the content of Comey's speech.

\footnotetext{
233 "Letter to the FBI director James Comey - Warsaw, April 21, 2015," The Institute of National Remembrance, http://ipn.gov.pl/en/news/2015/letter-to-the-fbi-director-james-comey-warsaw,-april-21,-2015

${ }^{234}$ As Poles frequently point out, Yad Vashem recognizes more Poles among the Righteous Among the Nations than any other nationality; "Names and Numbers of Righteous Among the Nations - per Country \& Ethnic Origin, as of January 1, 2015," http://www.yadvashem.org/yv/en/righteous/statistics.asp.
} 
In many ways, Poles have done an admirable job engaging with their history, which ought to be a source of national pride and international encouragement. Nevertheless, there are also always disturbing tendencies that arise whenever the Memory Wars enter into public discourse. It would be a terrible shame to see the advances made in the process of Poland's Vergangenheitsbewältigung slip away in the coming years as a result of nationalist right-wing hostility. Ever since the release of Shoah and the publication of "The Poor Poles Look at the Ghetto," Poles have embarked upon an important period of reevaluation of Poland's wartime experiences, which has profoundly impacted Polish collective memory and the country's attitude toward Jews. The core issues in these debates, which were also highlighted by the controversies over Auschwitz, have left a powerful mark on the Polish public sphere. The Memory Wars reached their zenith with Gross and the debate spawned by Neighbors. While Błoński had his defenders within Poland, Gross's book represented the first moment in which many Poles acknowledged the country's own history of anti-Semitic violence. Additionally, Polish politicians stepped up and addressed these controversies and often in a way that expressed remorse and a desire for atonement. Compared to the rest of Central and Eastern Europe, where forgetfulness toward the local circumstances behind the disappearance of Europe's Jews too often reigns supreme, this is virtually unprecedented. Polish artists and filmmakers have also played a crucial role in the unraveling of Poland's national memory. Indeed, films like Poktosie and Ida have helped to challenge the narratives of victimization and heroism, thereby offering a more complete account of Polish history.

The debates over Gross's Fear and Golden Harvest are more difficult to assess. Gross was, quite disturbingly, accused of criminally distorting the facts in his assault on Polish national mythology, which was a major step in the wrong direction for Poland. Yet it is also reassuring 
that Gross was never forced to defend himself against these absurd charges in court. While both books constitute important additions to the literatures on the Polish-Jewish past, perhaps it is time to consider new ways to address Polish-Jewish relations. Jan Tomasz Gross has done extraordinarily important work in this regard, and he should be commended for his role in these debates. For the Memory Wars, at the risk of being too hyperbolic, Gross arguably represents what Napoleon represents to the Napoleonic Wars; in short, it is inconceivable that the state of reassessing Polish memory could be where it is today without Gross's accomplishments.

However, the time for Gross's more strident approach has probably passed. Jan Gross is now a figure that is far too polarizing for many Poles, and anything he might contribute on the topic of Polish-Jewish relations in the future will only likely exacerbate the extremely hostile and ultra-nationalistic reactions that his most recent works on the subject have elicited. As time passes and the wounds of memory heal, it is likely that Gross's harshest critics will become less and less prominent and perhaps the day will come when Poles will wonder why these debates engendered so many hysterical responses in the first place. Tone ultimately matters a great deal, and much of the future of Polish-Jewish relations depends on how the Polish-Jewish past is presented to the broader public, which as recent empirical data shows still retains anti-Semitic attitudes and prejudices. The Polin Museum, with its emphasis on life rather than death, is one hopeful way of increasing Polish understanding of the country's minority Jewish heritage, which is an important part of Poland's history.

It is also crucial to try to reformulate these debates in a way that emphasizes clarity and analytical precision. When scholars and officials discuss these complex and vexing issues, it is necessary to be careful how philosophically controversial terms like "collective responsibility" are employed. Indeed, far too often Poles reject the critics of national memory because they see 
it as a closed-minded indictment of their entire nation. These issues need to be confronted in a serious and sensitive way. Finally, it is important to stress the successes of Poland's struggle with its history rather than focus solely on its failures. Few countries can say that they have come as far as Poland when it comes to engaging with the dark past of the Second World War, and few countries can claim that have made comparable strides toward reconciliation with those they have wronged. Poland's faults and failures should not be forgotten, but it is important to celebrate Poland's achievements. To excessively condemn the Polish nation indeed only strengthens the nationalistic and anti-Semitic trends in Polish memory. However much longer the Memory Wars last, there are encouraging signs that Poland is moving in the right direction on these issues. The process of Poland's Vergangenheitsbewältigung is slow and painful, but the reward is a kind of moral or spiritual regeneration that promises a future history that Poles can truly cherish and celebrate. 


\section{Bibliography}

Primary Sources:

Aderet, Ofer. "Watch: New Warsaw Museum tells story of Poland's Jews." Haaretz. Last modified October 28, 2014. http://www.haaretz.com/jewish-world/jewish-worldnews/.premium-1.622797.

Andrusz, Katya. "Polish President Condemns Vandalism of Jewish Massacre Memorial." Bloomberg. http://www.bloomberg.com/news/2011-09-02/polish-president-condemnsvandalism-of-jewish-massacre-memorial.html.

Bartana, Yael "Nightmares.” Filmoteka Muzeum, http://www.artmuseum.pl/filmoteka/?1=1\&id=200, April 29, 2013.

Betlejewski, Rafał. Płonie Stodoła, http://www.youtube.com/watch?v=r21 Jur404Lo, April 29, 2013.

Bilewicz, Michał, Mikołaj Winiewski and Wiktor Soral. “Antisemitism in Poland 2013:

Research Report based on Polish Prejudice Survey II." http://cbu.psychologia.pl/uploads/f_winiewski/PPS2\%20raporty/raport_antysemityzm_an g.pdf.

Brand, William, ed. Thou Shalt Not Kill: Poles on Jedwabne. Warsaw: Więź, 2001.

“Centre for Dialogue and Prayer in Oświęcim.” Accessed March 27, 2015, http://www.cdim.pl/en.

Chodakiewicz, Marek. The Massacre in Jedwabne. Boulder. CO: East European Monographs, 2004. 
Chodakiewicz, Marek, Muszynski Wojciech and Pawel Styrna, ed. Golden Harvest or Hearts of Gold? Studies on the Wartime Fate of Poles and Jews. SIS/Waller, 2012.

Cohen, Renae and Jennifer Golub. "Knowledge and Remembrance of the Holocaust in Poland." Working Papers on Contemporary Anti-Semitism, 1995.

Comey, James. "Why I require FBI agents to visit the Holocaust Museum.” Last modified April 16, 2015. The Washington Post. http://www.washingtonpost.com/opinions/the-scariestlesson-of-the-holocaust/2015/04/16/ffa8e23c-e468-11e4-905f-cc896d379a32_story.html.

“Core Exhibition - Grand Opening October 28, 2014.” http://www.polin.pl/en/exhibitions/coreexhibition-grand-opening-october-28-2014.

Ferfecki, Wiktor. “Potrzebne Muzeum Żydów.” Last modified October 29, 2014. http://www.rp.pl/artykul/1150204,1152982-Potrzebne-Muzeum-Zydow.html

Frilander, Aino and Heikki Aittokoski. "Arkkitehtuurin ensimmäinen Finlandia-palkinto: Rainer Mahlamäen puolanjuutalaisen historian museo Varsovassa." Last modified November 4, 2014. http://www.hs.fi/kulttuuri/a1305894111681.

Gross, Jan. Fear: Ant-Semitism in Poland after Auschwitz. New York: Random House, 2007.

Gross, Jan. Golden Harvest: Events at the Periphery of the Holocaust. Oxford University Press, 2012.

Gross, Jan. Holocaust in Occupied Poland: New Findings and New Interpretations, 2012.

Gross, Jan. Neighbors: The Destruction of the Jewish Community in Jedwabne, Poland. Princeton: Princeton University Press, 2001. 
Gruber, Ruth Ellen. "At last, Warsaw's Museum of the History of Polish Jews is dedicated," April 18, 2013, http://www.jewishjournal.com/culture/article/at_last_warsaws_museum_of_the_history_ of_polish_jews_is_dedicated

Kaufman, Michael T. "Debate over Holocaust stirs passion in Poland." New York Times, March 8, 1987, http://www.nytimes.com/1987/03/08/world/debate-over-holocaust-stirspassions-in-poland.html

Kotomski, Rafał. "Nasz wywiad: Chodakiewicz o "Pokłosiu." Niezalezna. http://niezalezna.pl/34816-nasz-wywiad-poklosie-powiela-falsz-historyczny

Kotomski, Rafał. “Nasz Wywiad: „Pokłosie” Powiela Fałsz Historyczny.” Niezalezna. http://niezalezna.pl/34816-nasz-wywiad-poklosie-powiela-falsz-historyczny

“Kielce: More Shame in Poland's History.” Jerusalem Post, July 1, 2001.

Lanzmann, Claude. Shoah: An Oral History of the Holocaust: The Complete Text of the Film. New York: Pantheon Books, 1985.

“Laureaci wg roku - 2014.” http://pnf.pl/laureaci-wg-roku-2014/.

"Letter to the FBI director James Comey - Warsaw, April 21, 2015.” The Institute of National Remembrance. http://ipn.gov.pl/en/news/2015/letter-to-the-fbi-director-james-comeywarsaw,-april-21,-2015.

Łuksza, Krzysztof. "Ida to antypolska propaganda - recenzja." Last modified February 24, 2015. http://wokolzycia.blox.pl/2015/02/Ida-recenzja.html. 
Lyman, Rick. “Poland Demands Apology Over F.B.I. Director's Holocaust Remarks.” The New York Times. http://www.nytimes.com/2015/04/21/world/europe/poland-angry-jamescomey-fbi-director-holocaust.html?_r=0.

Matyjaszek, Konrad. "Polinizacja historii. O wystawie stałej Muzeum Historii Żydów Polskich.” Last modified March 24, 2015. http://kulturaliberalna.pl/2015/03/24/konrad-matyjaszekmhzp-wystawa-stala-recenzja/.

McFadden, Robert D. "Glemp Pledges Better Interreligious Ties.” New York Times, October 7, 1991.

"Museum of the History of Polish Jews: Hearing before the Commission on Security and Cooperation in Europe: One Hundred Tenth Congress: Second Session.” Washington DC, U.S. Government Printing Office, 2011.

“Muzeum Historii Żydów Polskich.” Last modified February 2, 2011. http://szrm.pl/inwestycje/zrealizowane/muzeum-historii-zydow-polskich-3/

"Names and Numbers of Righteous Among the Nations - per Country \& Ethnic Origin, as of January 1, 2015." http://www.yadvashem.org/yv/en/righteous/statistics.asp.

"Netanyahu at Auschwitz: Never again." last modified January 27, 2010, The Jerusalem Post. http://www.jpost.com/International/Netanyahu-at-Auschwitz-Never-again.

Nieśpiał, Tomasz. “ABW do Jedwabnego.” Rzeczpospolita. http://www.rp.pl/artykul/17,710609ABW-szuka-wandali--ktorzy-zniszczyli-pomnik-w-Jedwabnem.html.

Pasikowski, Władysław. Pokłosie. Apple Film Production, 2012.

Pawlikowski, Pawel. Ida. Canal+ Polska, 2013. 
Pawłowski, Roman “Otwiera się interaktywne Muzeum Historii Żydów Polskich. Czyli pierwsze muzeum historii Polski.” Last modified October 27, 2014. http://wyborcza.pl/1,75475,16869612,Otwiera_sie_interaktywne_Muzeum_Historii_Zyd ow_Polskich_.html

Perlez, Jane. “Pope Orders Nuns out of Auschwitz.” New York Times, April 15, 1993.

"Poland asks Jews for forgiveness on 70th anniversary of Yedvabne massacre." Haaretz. http://www.haaretz.com/print-edition/news/poland-asks-jews-for-forgiveness-on-70thanniversary-of-yedvabne-massacre-1.372579. April 11, 2013.

"Poles born anti-Semitic, Shamir says." Globe and Mail. September 9, 1989.

Polonsky, Antony, ed. My Brother's Keeper? Recent Polish Debates on the Holocaust. London: Routledge, 1990.

Polonsky, Antony and Joanna Michlic, ed. The Neighbors Respond: The Controversy over the Jedwabne Massacre in Poland. Princeton: Princeton University Press, 2004.

Płużański, Tadeusz. “Nowe Pokłosie.” Last modified January 7, 2015. http://niezalezna.pl/63018-nowe-poklosie.

Rittner, Carol and John K. Roth, ed. Memory Offended: The Auschwitz Convent Controversy New York: Praeger, 1991.

Schwartz, Adi. "Historian threatens to reveal Polish atrocities against Jews if tried for slander." Haaretz. http://www.haaretz.com/news/historian-threatens-to-reveal-polish-atrocitiesagainst-jews-if-tried-for-slander-1.237256. 
Snyder, Donald. "Poll reveals anti-Semitism in Poland, renews debate over hate-speech laws." Last modified November 16, 2014. http://www.foxnews.com/world/2014/11/16/pollreveals-anti-semitism-in-poland-renews-debate-over-hate-speech-laws/.

Snyder, Donald. "Poland Poll Reveals Stubborn anti-Semitism amid Jewish Revival Hopes." Last modified January 18, 2014. http://forward.com/news/world/191155/poland-pollreveals-stubborn-anti-semitism-amid-je/.

Snyder, Donald. "Study: Polish anti-Semitism is widespread." National Catholic Reporter. March 28, 2014, 9.

Świrski, Maciej. “Umieszczenie informacji o kontekście historycznym, w jakim odbywa się akcja „Idy” - jest konieczne.” Last modified February 23, 2015, http://wpolityce.pl/kultura/234837-umieszczenie-informacji-o-kontekscie-historycznymw-jakim-odbywa-sie-akcja-idy-jest-konieczne

Szacki, Wojciech. “Sondaż: Nie boję się ciebie, Żydzie.” Gazeta Wyborcza. http://wyborcza.pl/1,76842,9063597,Sondaz_Nie_boje_sie_ciebie_Zydzie.html.

Szaynok, Bożena. Pogrom Żydów w Kielcach, 4 lipca 1946 r. Warsaw: Bellona, 1992.

Szczęsna, Joanna. “25 lat sporów o 'Shoah.”" Gazeta Wyborcza. http://wyborcza.pl/2029020,76842,7694169.html.

“Szef FBI żałuje swojej wypowiedzi.” Last modified April 23, 2015. http://www.rp.pl/artykul/1195855.html.

US State Department. “Contemporary Global anti-Semitism: A Reports Provided to the US Congress.” http://www.state.gov/documents/organization/102301.pdf. 
"Ustawa z dnia 18 grudnia 1998 r. o Instytucie Pamięci Narodowej - Komisji Ścigania Zbrodni przeciwko Narodowi Polskiemu.” http://isap.sejm.gov.pl/DetailsServlet?id=WDU19981551016.

Zychowicz, Piotr. “Chodakiewicz: Ludzi należy rozliczać indywidualnie.” Rzeczpospolita. http://www.rp.pl/artykul/82902.html?p=1

Secondary sources:

Bankier, David., ed. The Jews are Coming Back: The Return of the Jews to their Country of Origin after World War II. New York: Berghan Books, 2005.

Bartov, Omer. Hitler's Army: Soldiers, Nazis, and War in the Third Reich. Oxford University Press, 1992.

Bauman, Zygmunt. Modernity and the Holocaust. Ithaca: Cornell University Press, 1989.

Beorn, Waitman Wade. Marching into Darkness: The Wehrmacht and the Holocaust in Belarus. Cambridge: Harvard University Press, 2014.

Bernstein, Richard. "Shoah (1985) an Epic Film about the Greatest Evil of Modern Times.” The New York Times. http://www.nytimes.com/movie/review?res=9805E5DC1E39F933A15753C1A96394826 0.

Bilewicz, Michał, Anna Stefaniak and Marta Wikowska. "Polish Youth Confronting the Jewish Past." In Reconciliation in Bloodlands: Assessing Actions and Outcomes in Contemporary Central-Eastern Europe, edited by Jacek Kurczewski. Peter Lang, 2013. 
Blobaum, Robert, ed. Antisemitism and its Opponents in Modern Poland. Ithaca: Cornell University Press, 2005.

Blobaum, Robert. Rewolucja: Russian Poland, 1904-1907. Ithaca: Cornell University Press, 1995.

Blustein, Jeffrey. The Moral Demands of Memory. Cambridge University Press, 2008.

Brody, Richard. "Witness: Claude Lanzmann and the Making of Shoah." The New Yorker. http://www.newyorker.com/magazine/2012/03/19/witness-5?currentPage=all.

Browning, Christopher. Review of Hitler's Willing Executioners, by Daniel Goldhagen. History and Memory 8, no.1 (Spring-Summer 1996): 88-108.

Burke, Peter. "History as Social Memory." In The Collective Memory Reader, edited by Jeffrey K. Olick, Vered Vinitzky-Seroussi and Daniel Levy. Oxford University Press, 2011.

Cashman, Greer Fay. "Rivlin in Warsaw: Saga of the Jews did not begin in Poland nor did it end in Auschwitz." Last modified October 28, 2014. http://www.jpost.com/Diaspora/Rivlinin-Warsaw-Jews-were-removed-from-Poland-but-Poland-was-not-removed-from-theJews-380070.

Davies, Norman. God's Playground: A History of Poland, Volume I and II. New York: Columbia University Press, 2005.

Ebert, Robert. "Review of Shoah" http://www.rogerebert.com/reviews/great-movie-shoah-1985.

Felman, Shoshana. “Film as Witness: Claude Lanzmann's Shoah,” in Holocaust Remembrance: The Shapes of Memory, edited Geoffrey H Hartman, 90-103. Cambridge, Ma: Blackwell Publishers, 1994. 
Forecki, Piotr. Reconstructing Memory: the Holocaust in Polish Public Debates. Peter Lang, 2013.

Genevieve, Zubrzycki. Crosses of Auschwitz: Nationalism and Religion in Post-Communist Poland. University of Chicago Press, 2006.

Gitelman, Zvi. "Collective Memory and Contemporary Polish-Jewish Relations," in Contested Memories: Poles and Jews during the Holocaust and its Aftermath, edited by Joshua D. Zimmerman. New Brunswick: Rutgers University Press, 2003.

Glowacka, Dorota and Joanna Zylinska, ed. Imaginary Neighbors: Mediating Polish-Jewish Relations after the Holocaust. Lincoln: University of Nebraska Press, 2010.

Goldhagen, Daniel. Hitler's Willing Executioners: Ordinary Germans and the Holocaust. New York: Alfred A. Knopf.

Gutman, Yisrael, Ezra Mendelsohm, Jehuda Reinharz, and Chone Shmeruk, ed. The Jews of Poland Between Two World Wars. Hanover: University Press of New England, 1989.

Haltof, Marek. "National Memory, the Holocaust, and Images of the Jew in Postwar Polish Films" in Polish National Cinema. New York: Berghahn Books, 2002.

Hicks, Jeremy. “A unique exploration of Poland's unspoken, unspeakable history - Ida is spectacular." last modified September 30, 2014, http://theconversation.com/a-uniqueexploration-of-polands-unspoken-unspeakable-history-ida-is-spectacular-32301

Himka, John-Paul and Joanna Beata Michlic, ed., Bringing the Dark Past to Light: The Reception of the Holocaust in Postcommunist Europe. Lincoln: University of Nebraska Press, 2013. 
Huener, Jonathan. Auschwitz, Poland, and the Politics of Commemoration, 1945-1979. Athens: Ohio University Press, 2003.

Judt, Tony. "The Past Is Another Country: Myth and Memory in Postwar Europe.” Daedalus 121, no. 4 (Fall 1992): 83-118.

Kant, Immanuel. Religion within the Boundaries of Mere Reasons: And Other Writings. Cambridge University Press, 1999.

Kertzer, David I. The Popes Against the Jews: The Vatican's Role in the Rise of Modern AntiSemitism. New York: Alfred A. Knopf, 2001.

Kundera, Milan. The Book of Laughter and Forgetting. London: Penguin, 1983.

Lewis, H.D. "Collective Responsibility.” The Journal of the Royal Institute of Philosophy 23, no. 84 (January 1948): 3-18.

Margalit, Avishai. The Ethics of Memory. Cambridge: Harvard University Press, 2002.

Marrus, Michael R., and Robert Paxton, Vichy France and the Jews. New York: Basic Books, 1981.

Michlic, Joanna Beata. Coming to Terms with the "dark past": The Polish Debate about the Jedwabne Massacre. Hebrew University of Jerusalem, 2002.

Michlic, Joanna Beata. Poland's Threatening Other: The Image of the Jew from 1880 to the Present. Lincoln: University of Nebraska Press, 2006.

Pamuk, Orhan. The Museum of Innocence. Alfred A. Knopf, 2009. 
Paxton, Robert. Vichy France: Old Guard and New Order, 1940-1944. New York: Alfred A Knopf, 1972.

Porter-Szücs, Brian. Faith and the Fatherland: Catholicism, Modernity, and Poland. Oxford University Press, 2011.

Pulver, Andrew. "Polish nationalists launch petition against Oscar-nominated film Ida." last modified January 22, 2015. http://www.theguardian.com/film/2015/jan/22/ida-oscars2015-film-polish-nationalists-petition.

Radzik, Lina. "Reconciliation.” Stanford Encyclopedia of Philosophy. Last modified May 11, 2015. http://plato.stanford.edu/entries/reconciliation/\#TruTel.

Reszke, Katka. Return of the Jew: Identity Narratives of the Third Post-Holocaust Generation of Jews in Poland. Boston: Academic Studies Press, 2013.

Rosenfeld, Alvin. Facing Jedwabne. New York: American Jewish Committee, 2002.

Rossino, Alexander B. Hitler Strikes Poland: Blitzkrieg, Ideology, and Atrocity. Lawrence: University Press of Kansas, 2003.

Smiley, Marion. "Collective Responsibility." Stanford Encyclopedia of Philosophy. Last modified June 14, 2010. http://plato.stanford.edu/entries/collective-responsibility/\#1

Snyder, Timothy. Bloodlands: Europe Between Hitler and Stalin. New York: Basic Books, 2010.

Śpiewak, Pawer. "Reconciliation with the absent: Poles and Jews in democratic Poland." In Reconciliation in Bloodlands: Assessing Actions and Outcomes in Contemporary Central-Eastern Europe, edited by Jacek Kurczewski. Peter Lang, 2013. 
Steinlauf, Michael. Bondage to the Dead: Poland and the Memory of the Holocaust. Syracuse University Press, 1997.

Sverdlik, Steven. "Collective Responsibility." Philosophical Studies: An International Journal for Philosophy in the Analytic Tradition 51, no.1 (January 1987):61-76.

Tammeus, Bill and Rabbi Jacques Cukierkorn. They Were Just People: Stories of Rescue in Poland During the Holocaust. Columbia: University of Missouri Press, 2009.

Tec, Nechama. When Light Pierced the Darkness. New York: Oxford University Press, 1986.

Till, Karen E. 'Reimagining National Identity 'Chapters of Life' at the German Historical Museum in Berlin.” In Textures of Place: Exploring Humanist Geographies, edited by Paul C. Adams, Steven Hoelscher, and Karen E. Till. Minneapolis: University of Minnesota Press, 2001.

Tomaszewski, Irene and Werbowski, Tecia. Code Name Żegota: Rescuing Jews in Occupied Poland, 1942-1945. Santa Barbara: Praeger, 2010.

Wasilewski, Witold. "The Birth and Persistence of the Katyn Lie." Case Western Reserve Journal of International Law 45 (2013).

Weinbaum, Lawrence: The Struggle for Memory in Poland: Auschwitz, Jedwabne and Beyond. Jerusalem: Institute of the World Jewish Congress, 2001.

Zimmerman, Joshua. Contested Memories: Poles and Jews during the Holocaust and its Aftermath. New Brunswick: Rutgers University Press, 2003.

Zimmerman, Lynn W. Jewish Studies and Holocaust Education in Poland. Jefferson, North Carolina: McFarland \& Company, 2014 